\title{
STRENGTHENING THE PROTECTION OF FINANCIAL CONSUMERS IN MONGOLIA'S BANKING SECTOR
}

Giacomo Giannetto, Massimiliano Gangi, and Shagi Altankhuyag

NO. 20

December 2019
ADB EAST ASIA WORKING PAPER SERIES 



\section{ADB East Asia Working Paper Series}

\section{Strengthening the Protection of Financial Consumers in Mongolia's Banking Sector}

Giacomo Giannetto, Massimiliano Gangi, and Shagi Altankhuyag

No. 20 | December 2019
Giacomo G. Giannetto is a principal financial sector specialist in the Public Management, Financial Sector, and Regional Coop Division, East Asia Department of the Asian Development Bank. Massimiliano Gangi and Shagi Altankhuyag are consultants for the ADB technical assistance project in Mongolia, Supporting Financial Sector Development and Stability. 
(C) 2019 Asian Development Bank 6 ADB Avenue, Mandaluyong City, 1550 Metro Manila, Philippines

Tel +6328632 4444; Fax +63286362444

www.adb.org

Some rights reserved. Published in 2019.

Printed in the Philippines.

Publication Stock No. WPS190581-2

DOI: http://dx.doi.org/10.22617/WPS190581-2

The views expressed in this publication are those of the authors and do not necessarily reflect the views and policies of the Asian Development Bank (ADB) or its Board of Governors or the governments they represent.

ADB does not guarantee the accuracy of the data included in this publication and accepts no responsibility for any consequence of their use. The mention of specific companies or products of manufacturers does not imply that they are endorsed or recommended by ADB in preference to others of a similar nature that are not mentioned.

By making any designation of or reference to a particular territory or geographic area, or by using the term "country" in this document, $A D B$ does not intend to make any judgments as to the legal or other status of any territory or area.

This work is available under the Creative Commons Attribution 3.0 IGO license (CC BY 3.0 IGO) https://creativecommons.org/licenses/by/3.0/igo/. By using the content of this publication, you agree to be bound by the terms of this license. For attribution, translations, adaptations, and permissions, please read the provisions and terms of use at https://www.adb.org/terms-use\#openaccess.

This CC license does not apply to non-ADB copyright materials in this publication. If the material is attributed to another source, please contact the copyright owner or publisher of that source for permission to reproduce it. ADB cannot be held liable for any claims that arise as a result of your use of the material.

Please contact pubsmarketing@adb.org if you have questions or comments with respect to content, or if you wish to obtain copyright permission for your intended use that does not fall within these terms, or for permission to use the ADB logo.

Corrigenda to ADB publications may be found at http://www.adb.org/publications/corrigenda.

Note:

In this report, "\$” refers to United States dollars and “MNT" refers to Mongolian tögrög.

The ADB East Asia Working Paper Series is a forum for stimulating discussion and eliciting feedback on ongoing and recently completed research and policy studies undertaken by the East Asia Department of the Asian Development Bank (ADB) staff, consultants, or resource persons. The series deals with key economic and development problems, as well as conceptual, analytical, or methodological issues relating to project/program economic analysis, and statistical data and measurement. The series aims to enhance the knowledge on Asia's development and policy challenges; strengthen analytical rigor and quality of ADB's country partnership strategies, and its subregional and country operations; and improve the quality and availability of statistical data and development indicators for monitoring development effectiveness.

The ADB East Asia Working Paper Series is a quick-disseminating, informal publication whose titles could subsequently be revised for publication as articles in professional journals or chapters in books. The series is maintained by the East Asia Department. 


\section{CONTENTS}

ACKNOWLEDGMENTS

ABBREVIATIONS V V V V V V V V V V

CURRENCY EQUIVALENTS $\quad v$

EXECUTIVESUMMARY vi

$\begin{array}{ll}\text { I. INTRODUCTION } & 1\end{array}$

II. THE MONGOLIAN BANKING INDUSTRY 2

III. THE INSTITUTIONAL AND LEGAL FRAMEWORK FOR CONSUMER PROTECTION 4

IV. RECOMMENDATIONS FOR STRENGTHENING FINANCIAL CONSUMER PROTECTION $\quad 7$

V. INFORMATION DISCLOSURE AND RULES ON UNFAIR SALES PRACTICES

VI. RECOMMENDATIONS FOR STRONGER DISCLOSURE REQUIREMENTS AND FAIR MARKET CONDUCT 14

VII. HANDLING AND MAINTENANCE OF CUSTOMER ACCOUNTS 19

VIII. RECOMMENDATIONS ON THE HANDLING AND MAINTENANCE OF CUSTOMER ACCOUNTS 20

IX. PRIVACY AND DATA PROTECTION FOR BANKING SERVICES 22

X. RECOMMENDATIONS FOR STRENGTHENING PRIVACY AND PERSONAL DATA PROTECTION IN BANKING AND FINANCIAL SERVICES 26

XI. ALTERNATIVE DISPUTE RESOLUTION 26

XII. RECOMMENDATIONS CONCERNING THE RESOLUTION OF DISPUTES AND THE ESTABLISHMENT OF A FINANCIAL OMBUDSMAN 27

XIII. THE INTERFACE BETWEEN COMPETITION AND FINANCIAL CONSUMER PROTECTION

XIV. RECOMMENDATIONS ON THE RELATIONSHIP BETWEEN

COMPETITION POLICY AND FINANCIAL CONSUMER PROTECTION 33

XV. CONCLUSIONS

$\begin{array}{ll}\text { REFERENCES } & 34\end{array}$ 


\section{ACKNOWLEDGMENTS}

The authors thank Amy Leung, director general, East Asia Department (EARD), for her support for this publication. We are grateful for the encouragement of Xiaoqin Fan, director, Public Management, Financial Sector, and Ying Qian, former director, Public Management, Financial Sector, and Regional Cooperation Division. Also appreciated are the peer review and comments on the draft paper by Enerelt Enkhbold, senior investment officer, Mongolia Resident Mission (MNRM), and Kelly Hattel, senior financial sector specialist, Southeast Asia Department.

The authors also acknowledge the support of Edith Joan Nacpil, EARD; Declan Magee, MNRM; and Rodel Bautista, Ma. Katrina Fernando, and Cynthia Hidalgo, Department of Communications, for their help in the publication process. 


\section{ABBREVIATIONS}

$\begin{array}{ll}\text { ABA } & - \text { Australian Bankers' Association } \\ \text { ADR } & - \text { alternative dispute resolution } \\ \text { AFCCR } & - \text { Agency for Fair Competition and Consumer Rights } \\ \text { ASIC } & - \text { Australian Securities and Investments Commission } \\ \text { BOI } & - \text { Bank of Italy } \\ \text { BOM } & - \text { Bank of Mongolia } \\ \text { DPSLA } & - \text { Deposits, Payment Settlements and Loan Activities } \\ \text { ESIS } & - \text { European Standardized Information Sheet } \\ \text { FRC } & - \text { Financial Regulatory Commission } \\ \text { FSP } & - \text { financial service providers } \\ \text { MOF } & - \text { Ministry of Finance } \\ \text { MOU } & - \text { memorandum of understanding }\end{array}$

CURRENCY EQUIVALENTS

(as of 13 December 2019)

Currency unit - togrog (MNT)

MNT1.00 $=\$ 0.0003674$

$\$ 1.00=$ MNT2,722.0 


\section{EXECUTIVE SUMMARY}

Mongolia's finance sector, despite several improvements, is still very fragile. One of the most urgent challenges is providing people with access to finance. A large portion of the population, particularly poor and rural residents, lack access to financial services. Borrowers face burdensome requirements when applying for credit. Financial literacy is weak, and the country does not have an adequate regulatory framework for financial consumer protection. The absence of an adequate framework impairs consumers in obtaining proper credit, effectively resolving complaints or ensuring that they are not victims of improper lending practices, among other matters.

The Bank of Mongolia, the Financial Regulatory Commission, the Ministry of Finance, the Authority for Fair Competition and Consumer Protection are each involved in financial consumer protection. However, gaps and overlaps in authorities have led to a lack of clear avenues for consumers to raise concerns about their rights. The expansion of financial technologies allowing for alternative channels for credit add to the need for proper protection of consumer rights.

This report provides analyses and recommendations primarily on the role of the Bank of Mongolia in supporting development of a sound regime for financial consumer protection. The development of financial consumer protection in Mongolia is still in its early stages. The report is a summary of work completed under the 2016 technical assistance project Supporting Financial Sector Development and Stability. ${ }^{1}$

1 ADB. 2016. Supporting Financial Sector Development and Stability. Manila (cofinanced by the Republic of Korea's e-Asia and Knowledge Partnership Fund). 


\section{INTRODUCTION}

A comprehensive legislative and regulatory framework for financial consumer protection, coupled with effective prudential supervision of financial services providers, helps to ensure that consumers are granted safe access to sound and fair banking and financial services. Increasingly, financial consumer protection and financial education are also viewed as contributing significantly to financial stability and financial inclusion. ${ }^{1}$ For example, it is now widely acknowledged that the mis-selling of financial products and services in the United States and the United Kingdom to uninformed consumers led to the financial crisis of 2007-2008 and subsequent economic recession.

The rationale for strong financial consumer protection rules, particularly in developing countries such as Mongolia, lies in the considerable imbalance of power, asymmetry of information and disparity in financial means between retail consumers and financial services providers. While financial services providers in Mongolia have full knowledge about the consumer products and services they offer, their customers often find it costly and time-consuming to obtain adequate information on the key features of financial services available to them. Consumers purchasing financial products and services for their personal consumption and not for professional use, especially those who are poor, are particularly at a disadvantage.

A main goal of consumer protection in financial services is to remedy, or at least reduce, these imbalances. Reducing information asymmetries and power imbalances to ensure consumers have the information they need to make reasoned choices can help improve efficiency, transparency, and access to financial markets. For low-income countries such as Mongolia, financial consumer protection and education is also key to achieving greater financial inclusion. Both consumer protection and financial education promote a more extensive use of financial services by all segments of the population because they increase confidence and knowledge about financial products.

Globally, technological innovation and liberalized access to financial markets by new firms has led to a wider range of available financial products and services. Some of these can be complex and difficult for consumers to understand. Particularly in low-income countries, individuals and households are not familiar with such products and services and struggle to understand the underlying risks and obligations and can be easily misled. They may also fall victim to unfair and unethical behavior, including irresponsible lending practices and the sale of unsuitable products.

There is a general agreement that consumers who are empowered with information and basic rights represent a relevant source of market discipline to the financial sector. They provide incentives to financial service providers to compete through better services at lower cost, rather than taking advantage of poorly informed consumers.

Even so, the most appropriate consumer protection framework depends on the specific country circumstances, particularly on the relative level of economic development. Therefore, the regime needs to be fine-tuned and adapted.

At the extreme, consumer protection rules that are not well calibrated could potentially harm the interest of consumers by reducing the willingness of financial services providers to provide services. On the other

1 The contribution of financial consumer protection to financial stability has been highlighted in many international fora. See, for example, Financial Stability Board “Consumer Finance Protection with particular focus on credit”, 2011, pp. 4-6. 
hand, when consumers are not adequately protected, particularly in emerging economies like Mongolia, they may lose trust in financial service providers, thereby restricting the growth of consumer financial markets. It is therefore important to consider local institutional, social and economic conditions.

Regardless of the country's social and economic conditions, certain basic, fair and transparent conditions must be met. These include:

- Transparency: consumers must be provided with complete, plain, digestible, adequate and comparable information about prices, terms and conditions, and inherent risks of financial products and services;

- Choice: financial service providers must be given incentives to compete based on fair, noncoercive and reasonable conduct in the supply of financial products and services and in the collection of payments;

- Redress: consumers must have access to inexpensive (or free) and speedy mechanisms to address complaints and resolve disputes with financial service providers without the need to go through lengthy proceedings; and

- Privacy: consumers' personal financial information must be adequately protected by financial services providers.

A critical review of the existing financial consumer protection framework in Mongolia follows this introduction. This assessment is the foundation for the ensuing recommendations on how Mongolian policymakers can improve the regulatory framework and supervisory oversight of financial consumer protection, and the role that the Bank of Mongolia (BOM) could play.

The analysis focuses on the banking industry in Mongolia, which currently accounts for over $90 \%$ of the entire financial services industry. However, a significant number of the proposed recommendations would be equally applicable to other financial markets such as insurance and investment and securities services, and to several unregulated services.

As the focus of this paper is on consumer protection and financial education, enhancing financial confidence and inclusion is only slightly covered in this note. Deposit insurance, an important component of financial consumer protection, is covered in other recent ADB work. ${ }^{2}$

\section{THE MONGOLIAN BANKING INDUSTRY}

Banking is by far the predominant component of the Mongolian financial industry, accounting for approximately 95\% of the overall financial sector ${ }^{3}$ and employing about 30,0000 workers in 2016.

Access to formal banking services has been growing rapidly in recent years. According to the World Bank Global Findex Database Report of 2017, around 93\% of the adult population in Mongolia held a bank account. Consequently, the protection of the rights of consumers of banking services is becoming relevant for a growing section of the population.

2 ADB. REG: Deposit Insurance Establishment. https://www.adb.org/projects/43074-012/main.

3 Financial System Mongolia. https://www.fsa.go.jp/en/glopac/introductory/Presentation13/Mongolia13.pdf. 
As of 31 March 2018, the Mongolian banking industry included 14 commercial banks; all but one are privately owned. ${ }^{4}$ The only state-owned bank operates as a private bank as it has not been assigned any specific public interest function. According to the 2017 State Budget Law of Mongolia, several stateowned enterprises are expected to be privatized, including the only state-owned bank. ${ }^{5}$

Despite the relatively large number of banks, the banking sector in Mongolia is quite concentrated: the top 3 banks account for about $70 \%$ of total market share and the top 5 banks account for over $86 \% .^{6}$ This high market concentration is partially explained by the small size of the market relative to total population and disposable income. The high concentration limits consumer choice. In addition, a high degree of cross-ownership may affect competition and efficiency in the industry.

The distribution of market shares has remained quite stable over the years. This may be due to limited competition among existing banks and significant barriers to customers' mobility: few customers seem willing and able to switch banks.

In 2018, Mongolian banks maintained a network of 1516 branches. ${ }^{7}$ While bank branch penetration rate is high compared to the population overall, Mongolia's large, sparsely populated territory means that geographical branch penetration is comparatively low. ${ }^{8}$ About $60 \%$ of Mongolia's 3 million people reside in urban areas, with one quarter of the population living in the capitol, Ulaanbaatar. The rest live in rural areas that are hard to reach because of vast distances, rugged terrain and limited transport. Consequently, while Mongolia has one of the highest banks branch penetration rates in the world, with 60 branches per 100,000 adults, its geographical branch penetration is one of the lowest with only 0.87 branches per thousand km2. The country's low population density makes the provision of traditional banking services outside of the large cities costly.

The relevance of banking services catering to individual consumers is shown by loan data. Around $30 \%$ of total loans go to individuals or households. ${ }^{9}$ Of these, about half are mortgage loans and the other half are consumer, pension, and salary loans.

While banking services have reached a sizeable share of the overall national population, insurance, investment and securities, consumer credit and other financial services are still relatively under-used.

4 DICOM Annual Report. 2015. pp. 11-15.

5 The MNT75 billion expected proceeds from its privatization will go to the State budget. http://www.ikon.mn/n/vox.

6 Article 3.1 .1 of the Banking Law defines banks as profit-seeking legal entities with paid-in capital consisting of cash funds invested by "...shareholders which bear financial liability to the extent of their invested capital, and are engaged in financial intermediary services such as taking deposits, extending loans on their own behalf and executing payments and settlements under a license from the Bank of Mongolia...".

7 Financial System Mongolia. https://www.fsa.go.jp/en/glopac/introductory/Presentation13/Mongolia13.pdf.

8 ADB. 2016. Payment System Modernization Project. Project Administration Manual. Manila.

9 Mongolia's ratio of nonperforming loans in January 2017 was 8.5\%. The ratio reached a high of $50.5 \%$ in December 1999 and a low of $2.8 \%$ in April 2008. Nonperforming loans amount to MNT1.047 trillion for a total loan amount of MNT12.1 trillion, as of end of 2016. Nonperforming loan ratios in Mongolia appear to be higher than in most other countries of the region. 


\section{THE INSTITUTIONAL AND LEGAL FRAMEWORK FOR CONSUMER PROTECTION}

Mongolia's institutional and legislative framework for consumer protection in banking services includes the following acts:

- The Constitution;

- The Civil Code;

- The Consumer Protection Law;

- The Law on Advertising;

- The Competition Law;

- The Banking Law; and

- The Law on Deposits, Payment Settlements and Loan Activities (“DPSLA Law”).

The Ministry of Finance (MOF) is responsible for legislation concerning the supervision and regulation of financial markets. The ministry also oversees the operations of the three agencies responsible for regulating and supervising consumer protection in financial markets: the Bank of Mongolia (BOM); the Financial Regulatory Commission (FRC); and the Agency for Fair Competition and Consumer Rights (AFCCR).

The BOM and the AFCCR oversee the banking industry's fair market conduct toward consumers. In addition to its monetary policy competences as Mongolia's central bank, the BOM holds statutory responsibility for the regulation and supervision of the industry. ${ }^{10}$

The BOM's institutional activities related to banking regulation and supervision so far have focused on ensuring that prudential standards are met. ${ }^{11}$ The central objective has been the maintenance of safe and viable banks and the prevention of systemic risk which could endanger the viability of the industry as a whole.

The current legislation explicitly directs the BOM to conduct its supervisory activities in the interest of depositors and customers. ${ }^{12}$ However, a clear mandate for market conduct regulation or financial consumer protection supervision has not been adequately detailed in the legal and regulatory provisions. Also, relatively few legal provisions in the current legislation deal with the protection of retail bank customers.

Until recently, the BOM has held the view that maintaining a safe, stable and sound banking system is the best way to ultimately protect bank customers. However, similar to what has been occurring in most other jurisdictions worldwide, in both developed and less developed economies, the focus has begun to shift towards ensuring fair dealing by the banks vis-a-vis retail customers.

10 "...For the purpose of protecting the interests of depositors and customers, the Bank of Mongolia shall establish a procedure for and issue regulations and instructions, and make decisions, undertake supervision and enforcement activities relating to: the licensing of banks; the requirements of banks; the maintenance of adequate paid in capital and liquidity assets; improving the security of the banking system; and regulation of banking activities...". Central Bank Law, Article 19.

11 The BOM can impose administrative sanctions for infringement of the rules related to banking supervision unless the violations constitute a criminal offence. Central Bank Law, Article 9, Clause 42.

12 ".... For the purpose of protecting the interests of depositors and customers, the Bank of Mongolia shall establish a procedure to issue regulations and instructions, and make decision, undertake supervision and enforcement activities relating to: the licensing of banks; the requirements of banks; the maintenance of adequate paid in capital and liquidity assets; improving the security of the banking system; and regulation of banking activities...". Central Bank Law, Article 19.1. 
As of March 2017, the BOM's Banking Supervision Department, responsible for prudential supervision, was made up of 57 employees. Neither the department, nor the bank as a whole, has a consumer protection unit or personnel specifically dedicated to supervising and regulating banks' market conduct and fair treatment of consumers.

However, in the recent past, the Banking Supervision Department, together with the Monetary Policy Department, have carried out on-site inspections, including reviews to verify compliance with existing rules on how to deal with individual customers.

In September 2014, a BOM Governor Decree included some provisions for consumer protection. ${ }^{13}$ The Decree stated that the independent members of boards of directors of banks are required to protect depositors' and consumers' rights, in addition to the responsibilities already set by the Company Law and the Banking Law. ${ }^{14}$ In particular, boards of directors must establish consumer protection policies and revise them on a regular basis for constant improvement. Such policies should include "knowing your customer" rules, means to disclose relevant information of products and services, and principles for handling customers and maintaining customers' data protection..$^{15}$ The Decree states that the BOM will monitor compliance with such requirements during annual inspections on good governance.

With proper support, legal and regulatory changes, the BOM does have the capacity to expand their scope to properly oversee implementation of a sound framework for financial consumer protection.

The AFCCR also holds institutional powers for consumer protection in the banking sector. In fact, the AFCCR is responsible for the enforcement of the general Consumer Protection Law, applicable to all industries and markets, including the financial and banking markets. ${ }^{16}$ The law contains provisions requiring that all traders (including banks) must provide truthful information with respect to the goods and services they provide ${ }^{17}$ and must refrain from entering into contracts that may unfairly mislead and harm consumers. ${ }^{18}$ The Consumer Protection Law defines consumers as natural persons who purchase goods or services for their personal or family use, and defines sellers as all forms of economic entities, no matter their legal status, that sell goods or services to consumers. ${ }^{19}$

13 Government of Mongolia, BOM Governor Decree A-131. 2014. Implementing Good Governance Principles in banks. Mongolia.

14 Procedure on implementing Good Governance Principles in banks: https://mongolbank.mn/documents/regulation/control_ check/CG-guidelines-update.pdf.

15 Check sheet for Good Governance: https://mongolbank.mn/documents/regulation/control_check/CG-guidelines-update. pdf.

${ }^{16}$ It should be noted, however, that the sanctions foreseen for violations of the Consumer protection law are extremely low (only up to MNT250,000). Whenever possible, the AFCCR tries to resort to the higher fines foreseen by the Competition Law. However, this approach has been quashed by the courts in several appeal proceedings.

17 "...Producers, sellers and contractors shall be prohibited from giving to consumers false information regarding the goods, works and services...". Consumer Protection Law, Article 12.8.

18 "...It shall be prohibited to conclude sales contracts or contract for works or services by misleading or using force which violate consumer rights...". Consumer Protection Law, Article 12.9.

19 "...For the purposes of this Law: 3.1.1. "Consumer" shall mean an individual who orders, purchases goods, receives or uses any services for personal and family use only rather than for commercial purpose; 3.1.2. "Seller" shall mean business entity or organization irrespective of the form of organization, sole proprietor or individual offering the goods to consumers... 
The AFCCR is also responsible for enforcing the Law on Advertising. This law gives the agency power to impose sanctions for violations such as misleading advertising in all industries, including in banking and financial markets. ${ }^{20}$

The Competition Law, also enforced by the AFCCR, states that enterprises (including banks) cannot circulate advertising producing harmful effects on competitors. ${ }^{21}$ At the same time, the Banking Law prohibits misleading advertising by banks. ${ }^{22}$ In this case, the BOM is responsible for supervising and imposing sanctions in case of non-compliance. ${ }^{23}$ The Banking Law also gives the BOM the mandate to intervene against "dominant firms" acting against consumers. ${ }^{24}$

The AFCCR holds statutory prerogatives to issue regulations and guidelines on principles and rules for consumer protection enforcement in specific industries, including, in principle, the financial markets.

However, the staff of the AFCCR is made up of only 36 persons. Of the 6 officers working on general consumer protection issues, only one covers banking and other financial services. ${ }^{25}$ The AFCCR receives around 70-80 complaints per month concerning financial services; clearly, the agency is not adequately equipped to deal with the volume of complaints.

The institutional overlaps between the responsibilities of the BOM and those of the AFCCR, and the lack of formal or informal coordination and consultation mechanisms, are impediments to a robust regime for financial consumer protection. Equally, no institutional coordination framework on financial consumer protection exists between the BOM and the FRC, even though some partial overlap exists. For example, banks also distribute non-bank financial products and services supervised by the FRC, such as insurance products.

Due in part to the capacity restraints of the AFCCR and their scope of expertise being outside of the financial sector, the BOM is better placed to take on core elements of financial consumer protection that are now shared unclearly. Regardless, a strong coordination mechanism must be in place.

20 “... Advertisement of banking activities shall be true based on actual indicator of bank's liquidity and other indicators provided by the banking law. The advertisement of banking activities shall always include the main terms and conditions of bank deposit contract. In respect of the production, placing and dissemination of advertisements for investment fund, banking, financial, insurance, and other services and activities connected with use and dispose of monetary means of legal entities and individuals, and of securities, the following shall be prohibited: citing quantitative information that does not bear a direct relation to advertised products; guaranteeing the size of dividends on common inscribed shares; advertising prior to the permission to be issued by the Financial Regulatory Commission to securities to be offered to the public; presenting any kind of guarantee, promise or proposal on the future effectiveness and profitability of security activities."

21 Competition Law, Article 12.1.3.

22 ".. Advertisements by the bank shall truly reflect its activities at a given time and shall be in conformity with the laws and legislation. The Bank of Mongolia shall prohibit particular advertisement of the bank if it is considered to have the following contents: If the bank's financial statements disclosed to the public contradict the actual financial position of the bank; are not consistent with the legislation...". Banking Law, Article 8.

23 ".... disclosure of fraudulent and biased information or advertisement and violation of Article 8 of this Law shall result in a fine of 200-250 times the minimum wage for a bank and its affiliate companies and subsidiaries and a fine of 5-25 times the minimum wage for the bank's executive director who was in office during the disclosure of such information...". Banking Law, Article 68.1.11.

24 “... In addition to the prohibitions as defined in provision 7.1 of this Law, a bank, its subsidiary and affiliate company shall not engage in the following activities: carry out or participate in activities aimed at providing the bank, alone or together with others, a dominant position in the financial markets, or creating unfair preferential position to itself or any third party...”. Banking Law, Article 7.4.1.

25 This information was gathered in February 2017. 


\section{RECOMMENDATIONS FOR STRENGTHENING FINANCIAL CONSUMER PROTECTION}

\section{Create a stronger and broader mandate for the BOM with respect to financial consumer protection regulation and supervision.}

Even though scattered provisions exist, a comprehensive and detailed legislative and regulatory framework with strong rules to protect consumers of banking services at large, and to oversee the market conduct of financial service providers, is still absent in Mongolia.

It is therefore important that the BOM, as the banking supervisor in Mongolia, be assigned a strong legal mandate to carry out financial consumer protection regulation and supervision. The mandate should be clearly spelled out in the Banking Law. Armenia provides a good example of a clear mandate. The Law on the Central Bank of Armenia was amended in 2008 to add "...ensure essential conditions for the protection of the rights and lawful interests of the financial system consumers..." to the list of Armenia's Central Bank's objectives. ${ }^{26}$

Such an amendment to Mongolia's Banking Law appears timely. The scope of financial consumer protection supervision should also be clearly specified in the legislation. It should be, at least initially, limited to retail products and services to ensure coverage of those who are more vulnerable to exploitation and abuse: i.e. individual consumers. It could then be extended to cover micro and small enterprises.

The legal mandate for financial consumer protection should be matched by adequate supervisory and enforcement powers to allow the BOM to carry out its responsibilities. An illustration of such powers can be seen in those assigned in Australia to the Australian Securities and Investments Commission (Box 1). Explicit powers given to the BOM should include:

- Rule-making powers: the power to issue binding regulations and guidelines in the area of market conduct regulation and consumer protection. In this case, rules tailored to specific products or business practices need to be issued;

- Oversight and monitoring powers; the power to request information, carry-out off-site and on-site supervision, and conduct "mystery shopping" for the purpose of consumer protection; and

- Enforcement powers: the power to impose remedial measures and to issue penalties in case of infringements of the consumer protection-related legislation and regulation. Remedial measures may, for example, require the financial service providers to undertake various actions within a given time-frame to remedy wrongful behavior ${ }^{27}$. Penalties should include (for particularly serious violations) the suspension or withdrawal of the license or authorization to operate.

${ }^{26}$ Adapted from written submission by the representative of the Central Bank of Armenia at the Asian Development Bank International conference in Ulaanbaatar on October 12, 2017.

27 Common remedial actions imposed by market conduct regulators include:

- Adoption of a new complaint-dealing management information system;

- Withdrawal of certain products from the market;

- Adequate training of staff or independent agents;

- Improvements to disclosure practices;

- Withdrawal or modification of marketing material; and

- Modification of remuneration and commission policies for staff or agents. 


\section{Box 1: The Australian Securities and Investments Commission Powers for Consumer Protection and Market Conduct Supervision}

The Australian Securities and Investments Commission (ASIC) is Australia's corporate, markets, financial services and consumer credit regulator, ASIC strives to ensure that Australia's financial markets are fair, transparent, and supported by confident and informed investors and consumers. ASIC uses a range of regulatory tools to enforce and promote compliance with the administered laws, and to improve consumer understanding and decision making. The regulatory tools available to ASIC include:

(a) Enforcement action-ASIC undertakes investigations, which may lead to enforcement action such as:

(i) criminal action;

(ii) civil action, such as civil penalty proceedings, corrective action (e.g. to correct misleading disclosure), and compensatory action (to recover compensation on behalf of consumers); and

(iii) administrative action (e.g. banning or disqualifying persons from the financial services industry).

(b) Guidance-providing guidance to industry about how ASIC will administer the law to provide clarity to industry participants about their obligations under the law. ASIC achieves this by issuing regulatory guides, consultation papers, reports and information sheets.

(c) Surveillance-gathering and analyzing information on a specific entity or range of entities, a transaction, or a specific product or issue of concern in the market to test compliance with the laws and look at consumer and investor outcomes. After a surveillance, ASIC may publish its findings to inform the market or take further action, such as commencing an investigation with a view to carrying out enforcement action.

(d) Negotiated outcomes-these may arise from surveillance or investigations and include enforceable undertakings. An enforceable undertaking is a written undertaking given to ASIC that an entity or person will operate in a certain way. It is a flexible and effective remedy in improving compliance with the law and may be enforced through the courts.

(e) Education-undertaking educational activities, including financial literacy work.

Source: Adapted from the ASIC representative written contribution at the ADB International Conference in Ulaanbaatar on October 12, 2017.

In addition to the legal mandate, the BOM should adopt one or more regulations dealing directly with rules on consumer protection and the fair treatment of consumers by financial service providers to give clear guidance on the application of the consumer protection mandate.

\section{Eliminate the overlapping BOM and AFCCR competences in financial consumer protection through amendments to the legislation.}

Institutional competences for consumer protection supervision and enforcement in the Mongolian banking industry are presently assigned to two different public bodies: the national banking supervisor (the BOM), and the national consumer protection and competition enforcement agency (the AFCCR). The competences of the two institutions, largely overlapping, have been assigned on the basis of sector-specific or general legislation respectively. Both the BOM and the AFCCR hold a statutory mandate for:

- Consumer protection rule-making and supervision in the banking industry on the basis of the Banking Law and the Consumer Protection Law;

- Enforcement of the rules banning misleading advertising on the basis of the Banking Law and the Advertising Law; and

- Enforcement of rules against banks holding a dominant position liable to restrict competition on the basis of the Banking Law and the Competition Law. 
The risk of duplicative efforts by the two agencies appears real. Any duplication would be detrimental, particularly given the very limited resources available to the AFCCR for consumer protection enforcement and to the BOM for banking supervision. Therefore, even though a concurrent mandate is sometimes present in jurisdictions with both a banking market conduct regulator and an across-the-board consumer protection agency, such institutional arrangements do not seem appropriate for the Mongolia setting.

In fact, in view of the limited resources available to the AFCCR and its lack of in-house expertise on financial markets, it seems excessively burdensome for the AFCCR to exercise an adequate role for consumer protection supervision. The AFCCR's responsibilities for the enforcement of consumer protection as well as competition legislation appear to be daunting tasks that clearly require an efficient use of limited human and financial resources.

In the short-term, following consultations and a mutually agreed approach, the BOM should take the primary, if not exclusive, role in regulating, supervising and enforcing consumer protection in the banking industry. In order to reach a clear allocation of responsibilities between the BOM and the AFCCR, a memorandum of understanding (MOU) should be jointly drafted and adopted by the two institutions.

The MOU should clearly spell out the assignment of responsibilities between the two institutions in the area of financial consumer protection. It should also foresee regular consultations and exchanges of information concerning supervisory activities related to consumer protection in banking and other financial services.

In the long-term, an amendment to the Banking Law, the Advertising Law and the Consumer Protection Law would be advisable to eliminate duplication and assign an exclusive role for consumer protection in the banking industry to the BOM. In parallel, adjustments should be made to ensure that competition law enforcement is an exclusive AFCCR responsibility. Again, there seems no need to duplicate efforts in enforcing competition legislation. ${ }^{28}$

\section{Establish a market conduct supervision unit within the BOM with adequate powers and sufficient administrative capacity.}

An autonomous unit called, for instance, Market Conduct Supervision Unit (MCS Unit), should be established within the BOM to implement an adequate consumer protection regulatory and supervisory role. The Unit would be responsible for drafting consumer protection regulations and guidelines and for carrying out consumer protection supervision and enforcement.

Initially, the BOM could choose to place the MCS Unit within the Supervision Department. However, in the long-run, a clear separation of the consumer protection department from the prudential supervision department is preferable. Coordination of the financial stability and consumer protection objectives may be challenging and may result in a perceived conflict of interests. Therefore, exchange of information, coordination and consultation between the prudential supervision and the consumer protection departments will be essential.

Initially, an MCS Unit staff of 4-5 officers dedicated to consumer protection enforcement would probably suffice. The size of the unit may be later increased if deemed necessary. The staff should be made up

\footnotetext{
${ }^{28}$ It would also be useful to introduce a statutory requirement for the AFCCR to obtain a non-binding opinion by the BOM before adopting decisions on infringements of the competition legislation in the banking industry.
} 
of officers from a variety of backgrounds, considering that consumer protection supervision is a new area with evolving activities. Required skills for the conduct of financial consumer protection supervision should include research and analysis, legal skills, and knowledge of economics and communications. Good knowledge of the financial products and services available in the market would clearly be relevant.

Previous experience in prudential supervision work by the MCS Unit staff may be useful but should not be a requirement. In fact, prudential supervision and consumer protection supervision differ significantly. Prudential supervision focuses more on quantitative skills and analysis of an institution's financial soundness. Consumer protection supervision, on the other hand, is more qualitative in nature and focuses on how financial institutions deal with consumers.

\section{Box 2: Consumer Protection Supervision for Banking Services in Italy}

The Bank of Italy ("BOI") is responsible for both prudential and consumer protection supervision with respect to banking and payment services in Italy. To ensure an adequate level of financial consumer protection, $\mathrm{BOI}$ follows a supervisory approach based on three principles:

1. close integration of on-site and off-site controls;

2. quantitative and qualitative assessment of risks; and

3. close relations between the results of analyses and remedial actions.

$\mathrm{BOI}$ requires regulated banks and other financial service providers to comply with the $\mathrm{BOI}$ rules on transparency and fair treatment of customers. The objectives are to enhance public confidence in individual banks and financial service providers, and to contribute to the stability of the financial system as a whole. In this regard, $\mathrm{BOI}$ carries out regular controls on banks, credit, and payment service providers to assess and verify compliance with rules related to disclosure, transparency, and business conduct. Controls focus increasingly on the organizational arrangements adopted by financial service providers to ensure that the rules on transparency and the legal and reputational risks inherent in dealing with customers are considered in every stage of activity.

In particular, $\mathrm{BOI}$ can carry out on-site inspections at both financial service providers' headquarters and local branches around Italy. Inspections carried out at banks and financial service providers' headquarters are generally devoted to gathering information on the compliance of procedures and arrangements with the relevant provisions on fairness and transparency. Inspections at branches, on the other hand, focus on verifying compliance with fairness and transparency rules at the very end of the distribution channel; it is hence possible to gain direct knowledge of how financial service providers are organized and their everyday dealings with customers.

In pursuing its consumer protection objectives, $\mathrm{BOI}$ uses other sources of information. These include complaints submitted to the $\mathrm{BOI}$ and/or filed before the "Arbitro Bancario Finanziario" (the national Alternative Dispute Resolution body), and information gathered by the prudential supervisory units within $\mathrm{BOI}$. If the applicable regulatory provisions are breached, $\mathrm{BOI}$ has the power to, inter alia, require financial service providers to undertake corrective measures in their organizational structure and/or to revise the content of their disclosure and other contractual arrangements.

According to the principle of proportionality, $\mathrm{BO}$ may exercise its enforcement powers including, inter alia, issuing orders of reimbursement of sums unduly obtained by financial service providers in the execution of contracts with customers. In the most critical cases, $\mathrm{BO}$ can impose a suspension of businesses. Enforcement powers aim at preventing the continuation of activities harmful consumers, including specific forms of offer, advertising, or conclusion of contracts. $\mathrm{BOI}$ is also entitled to impose administrative pecuniary penalties for substantial breaches of the regulatory framework.

Source: Adapted from the written contribution by the Bank of Italy representative at the ADB International Conference in Ulaanbaatar on October 12, 2017. 
Similar to prudential supervision, a sound consumer protection supervision mechanism should be riskbased to optimize the use of scarce supervisory resources. This means that more efforts and resources should target riskier institutions or more pressing consumer protection issues. The proposed MCS Unit should be able to use a range of tools to carry out consumer protection supervision. Some of the tools used for prudential supervision can also be used for consumer protection. Additional tools, however, would also need to be employed.

The four main tools employed for consumer protection supervision purposes in many jurisdictions are:

- market monitoring;

- off-site examinations;

- on-site examinations; and

- enforcement actions (corrections and sanctions).

\section{Establish closer coordination between the BOM and the FRC in consumer protection matters.}

In Mongolia, as in many other countries, different kinds of financial services - banking, insurance, investment, non-bank credit, etc. - have distinct sector-specific consumer protection supervisors (BOM and FRC). Considering the growing similarity and substitutability among financial services, appropriate mechanisms must be in place to facilitate information exchange and to coordinate regulatory, supervisory and enforcement actions on a regular basis. This will ensure an identical level of consumer protection among different financial services.

It is important, therefore, for the BOM and the FRC to set up of regular meetings to exchange views and to resolve gaps and overlaps in consumer protection supervisory coverage.

One objective of such meetings would be to make sure that financial services with similar operational functions and features are subject to a similar type of consumer protection supervision, no matter the type of supplier involved. Coordination should ensure equal treatment among financial services providers and guarantee analogous consumer protection.

Cooperation between the BOM and the FRC could include institutional mapping of existing financial products and services available to consumers, including unregulated products and services. This process would identify areas of inadequate supervision under the existing regulatory framework. Such mapping should include financial services not regulated for prudential purposes but requiring consumer protection supervision (pawn shops, etc.). Initiatives should then be undertaken to close gaps clearly identify which institution is charged with supervising the identified "gap" area.

Where financial service providers offer a plurality of services as a primary or secondary activity, the primary regulator should establish close contacts with the other regulators to share information on common issues. Similarly, coordination mechanisms should exist between the BOM and AFCCR as long as financial consumer protection responsibilities are also shared with the general consumer protection authority.

\section{Strengthen the role of consumer organizations and of the Mongolia Bankers Association.}

The Mongolia Bankers Association (MBA) could play an important role in promoting fairer and more transparent treatment of consumers. The MBA, in consultation with the BOM and consumer organizations, should revise and upgrade its existing code of conduct to include comprehensive and 


\section{Box 3: The Australian Bankers' Association's Banking Code of Practice}

In 2018, ASIC, Australia's market conduct regulator for all financial markets, approved the revised Australian Bankers' Association (ABA) Banking Code of Practice. The code had already been in existence for more than 15 years. The updated code was reviewed by an independent expert following extensive consultations with financial regulators and consumer organizations. It built on and enhanced the consumer protections adopted in the 2013 version of the code.

The revised code contains provisions for inclusive and accessible banking including for vulnerable customers, customers on low incomes, and indigenous customers. It also provides for stronger protection of small business borrowers and expands the reach and impact of legal protections against unfair contract terms. For small businesses that borrow up to $\$ 3$ million, the code provides that lending contracts should not contain a range of potentially unfair and one-sided terms. All ABA member banks are required to subscribe to the code as a condition of their ABA membership, and the relevant protections form part of the banks' contractual relationships with their banking customers. The ABA will arrange for the code to be independently reviewed at least every three years from the date it comes into effect. When reviewing the code, the ABA will also consult with consumer representatives, small business organizations and other stakeholders.

Provisions in the code include:

\section{Key commitments of signatories}

- The Banking Code of Practice is a mandatory code of conduct which sets standards of good banking practice for the members of the ABA when they deal with individuals or with small business (defined as having less than 100 employees) customers.

- Signatories ensure that their staff have an adequate knowledge of the code, receive adequate training about the code, and provide banking services in compliance with the code.

$\underline{\text { Information that code signatories will provide about their banking services }}$

- Signatories make available the interest rates and the standard fees and charges to prospective customers for use in the preparation of a comparison rate.

- When they open an account with cheque access, customers are informed of the time generally taken for clearing a cheque and how and when a cheque may be stopped.

\section{Banking services practices}

- Prior to concluding a foreign currency loan, the code signatories will provide customers with a general warning in writing of the risks arising from exchange rate movements and of the availability of mechanisms for limiting such risks.

- Customers will receive a statement of all transactions relating to their deposit account at least every 6 months unless no amount has been debited or credited to the account during the statement period.

- If customers experience financial difficulties with a credit facility, signatories will try to assist by, for example by developing a repayment plan.

\section{$\underline{\text { Resolution of Disputes }}$}

- Code signatories will have an internal process for handling disputes which is free and accessible. When a complaint is submitted, customers will be notified of the name and contact number of the person who is investigating the dispute. Code signatories will complete the investigation and inform of the outcome of the investigation.

- To monitor effective compliance with the code, a Code Compliance Monitoring Committee is created. The committee is made up of 1 representative of the $A B A, 1$ representative of the consumer organizations and 1 expert appointed jointly by the Financial Ombudsman and ABA.

Source: The Banking Code of Practice 2019. 
in-depth quality standards on how banks deliver their services. The MBA should also have an internal mechanism to carry out monitoring of compliance with the code.

The revised code of conduct should detail quality standards binding on all associate members, on top of the BOM provisions providing rights to consumers. When revising the code, the MBA could consider the codes of conduct adopted in recent years in Australia and South Africa. A brief overview of the content of the Australian code is presented in Box 3. It is extremely important to include a mechanism to ensure supervision of compliance, and intervention in cases of non-compliance, as in Australia.

The MBA's revised code of conduct should be publicized among all consumers by posting it on the MBA and individual banks' websites. It should also be made available at bank branches. In fact, the effectiveness of the code would depend on ensuring the vast majority of consumers are familiar with it.

In many jurisdictions around the world, including many low-income countries, consumer associations exercise an important role in advocating for consumer rights in banking services. This has not been, so far, the case in Mongolia, mainly due to very limited resources. The government should provide support for the development of consumer organizations that can play an active role with respect to banking and financial services.

\section{INFORMATION DISCLOSURE AND RULES ON UNFAIR SALES PRACTICES}

The BOM has not provided detailed guidance on the specific types of information that banks must include in their terms and conditions (contractual agreements). ${ }^{29}$ In particular, the BOM has not issued a comprehensive disclosure regulation or adopted a standardized glossary of terms to be used by banks in order to facilitate comparability among alternative offers.

In contrast with many other jurisdictions around the world, the BOM does not require banks to produce and make publicly available a standardized statement containing the key features of their main consumer financial products and services. ${ }^{30}$ Experience in other jurisdictions indicates that the adoption of a standardized key facts statement can help consumers choose the most convenient option. Behavioral economics studies have shown that, when flooded with too much information, consumers feel overwhelmed and their ability to process the information is weakened. It is therefore essential to focus consumers' attention on the most important aspects of products and services.

Setting minimum professional competence requirements for bank employees helps ensure compliance with consumer rights in the design and distribution of information materials. Currently, the BOM has not set minimum required levels of professional competence for those bank employees who deal with consumers or prepare information materials for consumers.

Further, the BOM has yet to adopt a regulatory provision requiring banks to gather and store adequate information about their customers' characteristics and objectives before recommending specific financial products and services.

29 Information that is necessary to allow for consumer choice usually includes: applicable charges, methodology used to calculate interest rates, actions in case of default, procedures for closing the account, reporting rules in case of unauthorized transactions, etc.

30 Some jurisdictions require financial service providers to obtain consumers' written acknowledgement that they have read the institution's key facts statement before finalizing the contractual arrangements. 
No "cooling-off" safeguard exists to allow bank customers to withdraw from a contract within a few days of signing. The same applies to distance sales contracts (over Internet, phone, etc.).

At present, a consolidated practice exists by which banks charge up-front costs (for example, a set-up or application fee and in some cases appraisal and legal fees) to any consumer seeking a loan. Such costs appear not to be clearly disclosed to the customers when they apply for a loan.

The Banking Law prohibits banks from imposing upon customers the purchase of services in addition to those already supplied to them. ${ }^{31}$ However, the BOM does not actively supervise compliance with this prohibition, and some banks do not comply - for instance, where insurance is required in order to grant a loan. ${ }^{32}$

The Law on Advertising requires all regulated companies to indicate in their print advertising the name of the authority that issued their license and the license number. ${ }^{33}$ However, the requirement to name the regulator does not apply to other media.

The Civil Code contains provisions that limit the discretion of all companies, including banks, to insert clauses in their standard contracts ${ }^{34}$ (i.e. pre-formulated contracts, not individually negotiated) that limit banks' liabilities provided by the law ${ }^{35}$ or banks' responsibility in case of damages. ${ }^{36}$

The Mongolian Banking Association's Code of Conduct requires banks to act with care. However, the code is quite vague and does not appear to provide for adequate consumer protection. Compliance is voluntary and no monitoring mechanism exists.

Internet and mobile banking services are widely used in Mongolia, but comprehensive BOM regulatory guidance to banks covering financial consumer protection in these services appears to be absent. Nor does the BOM provide guidance on policies governing electronic funds transfer.

\section{RECOMMENDATIONS FOR STRONGER DISCLOSURE REQUIREMENTS AND FAIR MARKET CONDUCT}

In general, banking regulators adopt information disclosure and transparency requirements to give consumers access to the main features of banking and financial services and underlying contractual

31 "...A bank shall comply with the following requirements...not to require the customer to use services of its subsidiaries, affiliate companies, branches or representative offices or other services as a pre-condition for receiving services of the bank...”. Banking Law, Article16.1.5.

32 For example, Golomt Bank and Bodi Insurance share the same ownership. When consumers of the Golomt Bank need to purchase insurance services, they are required to choose the Bodi Insurance as supplier.

33 "... A printed advertisement related to activities that require license must include the name of the authority issued the license and the serial number of such permission.”. Law on Advertising, Article 6.2.

34 ...Conditions offered by a party to another; that is not determined by law, but which specifies procedure clarifying law provisions, and that shall be used permanently and determined beforehand, shall be standard conditions of contract...." Civil Code, Article 200.1.

35 "....If the party, proposing to conclude a contract with a an individual not running a business, incorporates following conditions into the standard conditions of the contract, they shall be invalid...": "...if the proposing party is released from the liability, provided by law, to remind the other party to assume obligations or to give it sufficient time to perform obligations...". Civil Code, Article 202.2.9.

36 "...If the party, proposing to conclude a contract with a an individual not running a business, incorporates following conditions into the standard conditions of the contract, they shall be invalid..."; "...denying or limiting the responsibility for damages caused, due to an extreme carelessness or deliberate actions by the proposing party or its legal representative...". Civil Code, Article 202.2.9. 
arrangements. Information should be available before the purchase and during the contractual relationship.

Transparency and disclosure rules are usually applied to all banking services. Particular attention is given to the increasing share of services supplied through communications technologies such as the Internet and mobile communications. Information disclosure does not impact on the autonomous decisionmaking of banks with respect to the products and services they intend to supply. Rather, it contributes to the promotion of competition among market players, to the benefit of consumers.

\section{Adopt a regulatory requirement for banks to make available to consumers their general terms and conditions, as well as those which are product-specific.}

An important way to strengthen Mongolia's consumer protection framework for banking services is to implement a stricter requirement for banks to provide precise, clear, and complete information, in clear language, about their services.

Information to consumers should be clear and directly relevant to the consumers' choice. The key differences among alternative offers should be highlighted. The current regulatory framework for information disclosure for the banking sector could be improved through the adoption of few measures to strengthen consumer empowerment.

As a first step, BOM Regulation should establish a requirement for all banks to make available, free of charge, the terms and conditions applying to any specific banking product or service, as well as those which form the basis of the banks' operations before entering into any agreement with the customer.

Bank should be required to write these terms and conditions in plain language, avoiding technical jargon as much as possible, and in an adequately large font to allow for easy reading. Terms and conditions should include exhaustive information with respect to:

- The applicable fees and charges;

- Any additional amounts charged to the customer if circumstances arise (payment arrears, etc.);

- Information on the standardized methodology used to calculate interest rates debited or credited to the consumer;

- Information about any compensation scheme of which the bank is a member, in case of default or financial distress;

- A brief description of the bank's internal complaints procedures;

- Reference to the body (financial ombudsman, BOM, etc.) responsible to deal with complaints concerning specific products or services, in case the dispute cannot be settled directly between the bank and the consumer; and

- Clear reporting procedures that consumers are required to follow in case of stolen cards or unauthorized transactions.

\section{Introduce a requirement for banks to produce "key facts statements" sheets with reference to the main banking products and services.}

The BOM could consider introducing a requirement for regulated financial service providers to make publicly available and free of charge, to all potential and actual customers, key facts statements of approximately 1-2 pages about the key terms and conditions relating to loans and other products and services. 
Following consultations with the banking industry, the BOM could use the European Standardized Information Sheet (ESIS) template as reference. ESIS is the short note that financial service providers of Member States of the European Union must produce and make available to consumers in connection with the supply of mortgage loans. The ESIS could be a useful precedent for the BOM of an industry-wide compulsory summary or key facts statement. European financial services providers must include in the ESIS the following information:

- The main features and duration of the loan;

- Interest rates and other costs related to the loan;

- Frequency and number of payments;

- Amount of each instalment;

- Additional obligations;

- Possibility of and costs related to early repayment of the loan;

- Complaints procedures;

- Consequences for the borrower for non-compliance with the commitments (arrear penalties, etc.); and

- Supervisory institution.

Preparation and distribution of key facts statements would allow potential customers to easily compare offers from different financial service providers, thereby making a more reasoned and convenient choice. The summary statements would also be a useful remainder to consumers of their rights and obligations during the lifetime of the product or service.

To facilitate these objectives, the format and content of summary statements should be standardized for all market participants. The statements should be developed by the BOM in consultation with the Mongolia's Bankers Association and involve consumer organizations as much as possible. Before final adoption of the key facts statement, the BOM should carry out a test to ensure the format is easily understood by consumers.

The BOM could also require banks to have customers sign a note confirming they have received, read and understood the key facts statement before finalizing a financial service agreement. This requirement would be particularly appropriate for complex products such as mortgage loans.

\section{Require banks to gather adequate information about customers before recommending a product or issuing a loan.}

Where credit products are offered, the BOM should require banks to gather adequate information about the assets and liabilities of the customer to ensure the loan can be paid back. Responsible lending is an important component of consumer protection in many jurisdictions. For example, the member states of the European Union have adopted strict rules to ensure consumers are able to repay loans they are issued. The United States has similar rules. Mongolian banks should also be required to go over the terms of the agreement with the customer to make sure all obligations are fully understood.

The adoption of "know your customer" requirements would undoubtedly strengthen consumer protection. The amount of information to be gathered would necessarily relate to the complexity and riskiness of the recommended product. 


\section{Box 4: Responsible Lending in the European Union and the United States}

The European Union Mortgage Credit Directive introduced a harmonized framework on credit agreements related to residential property to enhance responsible mortgage lending. The directive established, for the first time, common standards for all EU member states with respect to the assessment of credit-worthiness (ability to pay back) in the context of mortgage lending.

Lenders are required to conduct an assessment of the borrower's ability to repay the loan before granting any credit. The assessment needs to be based on relevant sources and needs to be documented. Credit can be granted only after it can be safely concluded that the borrower is likely to meet his or her obligations related to the mortgage loan agreement. The directive also introduced the compulsory European Standardized Information Sheet (ESIS) to inform consumers at the pre-contractual stage about all features of the credit on offer, including inherent credit risks such as those linked to variable interest rates or foreign currency loans.

The provisions of the European Union's framework are outlined in Directive 2014/17/EU of the European Parliament and of The Council of 4 February 2014 on credit agreements for consumers relating to residential immovable property and amending Directives 2008/48/EC and 2013/36/EU and Regulation (EU) No 1093/2010.

In the United States, the Dodd-Frank Act sets forth minimum standards for residential mortgage loans. One of these standards (Ability-to-Repay rules) requires mortgage lenders to determine, "...based on verified and documented information..." that the consumer has a "...reasonable ability to repay the loan..." before the loan is consummated. Creditors are required to make the ability to pay determination based on the consumer's credit history, income, obligations, debtto-income ratio, employment status and other information, utilizing a fully amortizing payment schedule, and lenders should document their consideration of these factors.

Sources: European Commission. Mortgage Credit-Directive 2014/17/EU. https://ec.europa.eu/info/law/mortgage-creditdirective-2014-17-eu_en (accessed 16 December 2019); and Government of the United States of America. 2010. Public Law 111203 Dodd-Frank Wall Street Reform and Consumer Protection Act. Washington, DC. https://www.congress.gov/bill/111th-congress/ house-bill/4173/text?overview=closed $\& \mathrm{r}=1$.

\section{Adopt a "cooling-off" safeguard provision for specific banking products.}

Cooling-off provisions have become a common practice in the consumer protection laws of a few jurisdictions. These provisions allow the retail consumer to withdraw from service contracts for loans, long-term savings, or insurance instruments with no penalty, within 3 to 5 days from the date of signing the agreement. ${ }^{37}$

Cooling-off provisions are an extension of the consumers' right to know and to choose contained in various consumer laws. In fact, they add a new, independent right for consumers: i.e. the right to change one's mind, as well as an obligation for businesses. ${ }^{38}$

37 The "cooling-off" safeguard clause dates back to the 1964 Rental and Sale of Goods Act of the United Kingdom, which contained "cooling-off periods" clauses for door-to-door sales of products. Following the UK precedent, the US Consumer Credit Protection Act adopted by the US International Trade Commission in 1972 and amended in 1974, as well as the EU Directive on Long Distance Sales issued in 2000 and the EU Directive on Consumer Rights issued in 2008, have all included provisions on cooling-off periods, allowing consumers the right to revoke and cancel a transaction.

38 It is worth observing that the right to change one's mind and cancel a transaction, when exercised in practice, should never be excessively broad. 
Cooling-off provisions in financial services usually include a requirement for the consumer to reimburse the financial service supplier for any non-recoverable costs incurred. These provisions do not generally apply to financial products or services whose price is subject to short-term financial markets' fluctuations which may occur during the withdrawal period and which are outside the financial services provider's control. ${ }^{39}$

Some jurisdictions grant the right of withdrawal for the purchase of financial products and services through "distant communication", i.e. where there is no simultaneous physical presence of the supplier and the customer when the sale takes place. For example, the European Union has granted 14 calendar days for all products and 30 days for life insurance products as cooling off periods. ${ }^{40}$

The BOM should introduce a cooling-off safeguard provision in the Mongolian banking legislative and regulatory framework for some of the main banking products, such as loan agreements and other financial services, allowing consumers to walk away within 7 days from the signing of the contract.

\section{Introduce a ban on tied and bundled sales.}

Tied or bundled sales refers to the practice of making a product or service available only on the condition that the customer purchases another product from the same or a related company. For example, a bank informs a potential customer that he qualifies for a home mortgage, then later tells the customer is told that the bank will approve the loan only if he or she transfers his or her savings to the bank or its affiliates.

Tied or bundled sales restrict consumer choice and make comparison among products or services more difficult. They may also reduce competition in the market, as newcomers may find more difficult to access the market.

Many jurisdictions bar the use of tied sales unless justified for technical reasons. ${ }^{41}$ When the sale of a product is made conditional on the purchase of another product, the consumer should be left free to choose the supplier of the second product. ${ }^{42}$ Because tied sales are essentially unfair to consumers, the BOM should prohibit banks from this practice.

39 The EU Directive on the Distance Marketing of Consumer Financial Services lists among the financial services whose price depends on fluctuations in the financial market the following: "...foreign exchange, money market instruments, transferable securities, units in collective investment undertakings, financial-futures contracts, etc."

40 See Directive 2002/65/EC of the European Parliament and of the Council of 23 September 2002 Concerning the Distance Marketing of Consumer Financial Services and Directives 97/7/EC and 98/27/EC (Distance Marketing Directive). The Distance Marketing Directive covers contracts for retail financial services (banking, insurance, payment and investment services, including pension funds) that are negotiated at a distance and do not require the simultaneous physical presence of the parties to the contract (e.g. by telephone, fax or over the Internet).

${ }^{41}$ Article 3.17 of the Consumer Protection Code 2012 adopted by the Central Bank of Ireland states: “...regulated entity must not make the sale of a product or service contingent on the consumer purchasing another product or service from the regulated entity. This provision does not prevent a regulated entity from offering additional products or services to consumers who are existing customers which are not available to potential consumers...”.

42 In 2005, the European Commission of the European Union launched a sectorial Inquiry on the retail financial services sector. The inquiry's conclusions highlighted the low level of mobility of European customers. Among the main factors for this was the cross-selling of banking products, including tied or conditional sales. Tying practices were found to be a widespread practice across EU Member States. The inquiry focused in particular on five types of tied practices: (i) mortgages and current accounts; (ii) mortgages and the obligation to pay salary into current accounts, (iii) mortgages and life insurance; (iv) non-mortgage loans and current accounts and; (v) non-mortgage loans and the obligation to deposit a salary into a current account. The Inquiry was carried out pursuant to Article 17 of Regulation (EC) No 1/2003. The investigation focused on three main product areas: 1) payment cards services; 2) core retail banking services; 3) business insurance. The inquiry, concluded in 2007, provided a detailed picture of existing competitive conditions in the selected retail financial services. 


\section{Strengthen the ban on misleading advertising.}

The BOM should require banks to indicate in all their advertising and communications material that they are regulated entities, and provide the contact details of the regulatory institution.

It is important to eliminate the existing institutional and legislative overlap of the Banking Law and in the Advertising Law provisions that prohibit misleading advertising while assigning enforcement responsibilities to two different institutions: respectively the BOM and the AFCCR. Equally important is to ensure that fines for engaging in misleading advertising are sufficiently high to deter the practice. ${ }^{43}$

\section{Establish BOM requirements on minimum competency levels of banks staff dealing with retail customers.}

The BOM, following consultations with the MBA, should consider imposing minimum proficiency levels for bank employees dealing directly with customers or involved in preparing communications materials. The BOM could provide support to the MBA and the Banking Academy to develop curricula related to financial services and fair conduct for bank employees.

\section{HANDLING AND MAINTENANCE OF CUSTOMER ACCOUNTS}

The BOM does not require banks to provide to their customers regular (monthly, bi-monthly, etc.) account statements detailing transactions, interest rates, and other charges. The receipt of account statements on a regular and continuous basis is a valuable source of consumer protection since consumers can keep track of their accounts and intervene in case of fraud, error or negligence. ${ }^{44}$

Currently, banks inform customers about changes in interest rates or charges through posts on their website or announcements in the branches. There is no requirement for banks to provide advance notice of such changes or to allow consumers to exit from their bank agreements at no charge if they disagree with the new charges. It is only with respect to deposit accounts that the DPSLA Law allows customers to exit from existing contracts. ${ }^{45}$

\footnotetext{
43 In the European Union, the Directive banning unfair commercial practices across all markets (Directive 2005/29/EC of the European Parliament and of the Council of 11 May 2005 also called Unfair Commercial Practices Directive) considers misleading information in relation to:

1. The nature of the product or service;

2. The main characteristics of the product or service;

3. The price or the manner in which the price is calculated; and

4. The consumer's rights, including the right to reimbursement.

The EU directive applies to all markets. It allows Member States to introduce stricter standards against misleading practices in financial services markets. Stricter standards were, for example, adopted in the Republic of Ireland. Chapter 9 of the Consumer Protection Code 2012 issued by the Central Bank of Ireland contains more detailed provisions about the modalities financial services providers are allowed to advertise their financial products and services.

44 "Good Practices for Financial Consumer Protection", World Bank, June 2012.

45 "...If the interest rate payable on a non-fixed term deposit is changed by the depository, the interest rate set out in the deposit agreement for a non-fixed term deposit shall be deemed to be changed and interest at the new rate shall be payable one month following public disclosure of the new interest rate. In case of disagreement with the aforesaid condition a depositor may cancel the agreement...". Interest on Deposits of DPSLA Law, Article 6.4.
} 
Banks must receive approval from the BOM concerning the methodology employed to calculate interest rates charges. ${ }^{46}$ However, the BOM has not established a standard methodology to be complied with by all banks.

The BOM does not require banks to maintain updated files on customer accounts. There is no provision allowing customers to have access - free of charge or for a limited fee - to copies of their documents kept in the banks' files. The requirement to maintain a customer's file record appears to exist only for loan accounts under the provisions of the DPSLA Law. ${ }^{47}$

Other jurisdictions require banks to keep files that clearly identify the customer, indicate the products and services supplied to the customer, and record all correspondence with the customer, among others.

Mongolia has no specific law or BOM rule concerning the prevention of abusive or aggressive debt collection practices. Loan contracts do not specify how debt collection can take place. Only the Civil Code contains a provision which refers to debt collection practices. It states that relevant laws and international practices shall apply in collecting debt. ${ }^{48}$ However, it does not provide details about which laws or international practices would apply. As no debt collection companies exist in Mongolia, banks are directly involved in collecting outstanding debts.

The BOM has no regulations on how banks should inform consumers about court proceedings to foreclose property used as collateral for mortgage loans. Further, banks are not required to offer debtrescheduling to avoid court proceedings, which are costly for customers. Finally, there are no regulations on how banks should inform customers about any decision to render them bankrupt.

\section{RECOMMENDATIONS ON THE HANDLING AND MAINTENANCE OF CUSTOMER ACCOUNTS}

\section{Institute a BOM requirement for banks to provide regularly account statements to retail customers.}

As mentioned, the BOM has not yet adopted a regulatory requirement for banks to provide retail customers with monthly statements of their accounts. Some banks voluntarily provide such statements, but others do not. The BOM should therefore adopt a regulatory requirement for banks to make available, free of charge, monthly account statements to their customers for each account they hold. This requirement should remain valid and binding on the financial service supplier unless the customer explicitly agrees to waive it.

\footnotetext{
46 “...The Mongolbank shall approve the methodology for the calculation of the interest rate on deposits...”. Deposits of DPSLA Law, Article 6.5.

47 “... 1. The lenders shall establish and maintain a file in the name of each borrower. 2. The file shall consist of the following forms:1) a loan application; 2) a loan agreement; 3) a statement of assets and their value to be offered as security for the loan, certificate of registration in case of immovable property and an analysis of the guarantor of the loan and the guarantee documentation; 4) plans for the project to be financed, and reviews and confirmations of such plans by the appropriate authorities, any amendments made to those plans, any associated documentation, progress reports, contracts, and profitability forecasts; 5) a report of an independent auditor and subscriber; 6) financial statements; 7) documents verifying the use of the loan; and 8) a report on any other bank loans held in the name of the borrower..". Law on Deposits, Loans and Banking Transactions, Article 23.

48 “... The Law, international standards and business practice shall apply for executing the payments with order of collection...”. Civil Code, Article 450.2.
} 
Account statements should include information about all transactions that occurred during the reporting period, as occurs in other jurisdictions around the world. In particular, they should reflect fees and interest rates charged or credited, including penalty charges in case of payment arrears. For mortgage loans, the account statement should show payments made and the outstanding balance.

\section{Require banks to inform customers in advance about any proposed change in their charges or other contractual conditions.}

The BOM should require banks to notify their customers individually in writing - and with reasonable advance notice - about changes in contractual conditions, interest rates, or other fees they charge to their customers' accounts. When customers do not agree with the new financial conditions, they should be allowed the option of closing the account within a reasonable time without penalty. For loans with variable interest rates linked to an international index such as Libor, contracts should specify how the bank will inform customers about interest rate changes.

For example, the Bank of Italy 2009 Regulation Transparency of Banking and Financial Operations and Services and Financial institutions' fair dealing with customers requires banks to provide information in writing to each customer about proposed contractual changes at least 30 days in advance from their entry into force. If the customer does not pull out of the contract within 60 days, the changes are considered approved. If the bank does not comply with advance notification procedures, the changes cannot be implemented lest they worsen conditions for customers. At least once a year, banks are required to send each customer a document, either by mail or electronically, containing the contractual conditions applied. Charges to customers should not be higher than the actual postal costs. At their expense, customers have the right to obtain information within a period not exceeding 90 days on each single bank operation taken in the previous ten years. The bank informs the customer at the moment of the request about the involved cost.

\section{Require banks to maintain customer files for an adequate time.}

The BOM should implement a regulation requiring banks to maintain an up-to-date file for each customer in relation to each account and indicating the minimum time period the file must be maintained. Customers should be given access to copies of the documents contained in the banks' file free of charge or for a reasonable, cost-related, charge. Each customer file could include:

- Customer details and documents used for the customer's identification;

- All products and services provided to the customers; and

- All correspondence exchanged with the customer, including account statements.

\section{Adopt consumer protection rules for debit and credit cards and for internet and mobile banking.}

The BOM should require banks supplying credit and debit cards to disclose in writing and in advance to their customers all the applicable terms and conditions. Any change in charges and interest rates should be communicated to the customer with a reasonable advance notice. ${ }^{49} \mathrm{~A}$ clear and sound system should also be put into place for reporting unauthorized transactions or stolen cards.

\footnotetext{
49 No charges or fees should be imposed with respect to pre-approved credit cards that have not been requested by consumers. However, such practice does not appear to occur in Mongolia.
} 
The BOM should also consider adopting a clear regulatory consumer protection program governing internet and mobile banking services, supervised by the BOM. Banks should put in place a declared security program that would guarantee adequate data privacy and integrity and prevent fraud and identity theft. Customers should also be informed in advance about the costs of using internet and mobile banking services and given sufficient advance notice in case of a temporary interruption of the service. Clear rules for error resolution and fraud prevention should be put in place. The BOM should introduce rules requiring banks to provide written information about the features and charges related to electronic funds transfers.

\section{Provide guidance to ensure consumer protection in debt collection activities.}

The BOM should prohibit banks from engaging in abusive debt collection practices, and this should be extended in future to agencies, such as debt collectors, acting on their behalf. An example of such rules is contained in the Fair Debt Collection Practices guidelines issued by the central bank of Malaysia. ${ }^{50}$ The guideline stipulates that debt collectors must never resort to intimidation or violence and must follow best practices, such as notifying borrowers in writing prior to initiating collection, providing evidence that the collection has been authorized by the financial services provider, and respecting the confidentiality of the borrower's information. The financial services provider is responsible for any misconduct by the agent. If a borrower believes that a third party has violated its obligations, a complaint can be lodged with the financial services provider. If the borrower is dissatisfied with the assistance they receive, the case can be submitted to the attention of the bank. The BOM should also require that all credit contracts include clauses which specify how debt will be collected.

\section{Adopt rules for protecting consumers facing mortgage collateral home foreclosures.}

The BOM should require banks to provide adequate advance notice to customers before initiating home foreclosure proceedings. In particular, detailed information about the foreclosure process and the options and the remedies available to the customer should be made available.

\section{PRIVACY AND DATA PROTECTION FOR BANKING SERVICES}

Three Mongolian laws relate to varying degrees to the protection of personal data and privacy in banking and financial transactions: the Law on Personal Privacy, the DPSLA Law, and the Banking Law.

The general Law on Personal Privacy has only limited direct applicability to banking and financial transactions..$^{51}$ Moreover, the penalties for violating rules related to the protection of personal data and privacy appear negligible. Therefore, the law does not guarantee an adequate deterrence effect vis-à-vis wrongdoers. The DPSLA Law requires banks "... to keep the details of the accounts of depositors confidential...". ${ }^{2}$ There are no additional or more detailed requirements to maintain the confidentiality of other sensitive information related to the customer. The Banking Law contains limited requirements related to the protection of personal data in relation to banking services. Under this law, members of

\footnotetext{
50 "Empowering and protecting financial consumers - Bank Negara Malaysia's consumer and market conduct framework", the Alliance for Financial Inclusion, 2011.

51 Adopted on April 21, 1995.

52 DPSLA Law, Article 7.2.5.
} 
banks' boards of directors and bank officers are forbidden from disclosing confidential information to third parties, with some exceptions based on the public interest. ${ }^{53}$

The BOM does not stipulate procedures for safeguarding the confidentiality of customers records, nor does it specify what types of information need to be kept confidential. A provision contained in article 7.2 of the Banking Law only states that "... information considered by bank, customer and third party as confidential should not be disclosed...". The BOM has no guidelines on how banks should protect customers' confidential information from intrusion and from cyber-attacks targeting banks' databases. ${ }^{54}$

The BOM does not require banks to inform their customers when the bank, by statute, must disclose the customer's financial information, including disclosure to Government authorities, and what use is to be made of that information. The BOM also does not explicitly prohibit banks from using personal data for mass mail-marketing purposes. According to article 7.2.2 of the Banking Law, the BOM and its inspectors in order to fulfill their legal obligations, have the right to information considered confidential by banks, customers and third parties.

In short, Mongolia lacks comprehensive and effective personal data protection legislation and implementing regulations to adequately safeguard banking and financial transactions. This includes legal provisions requiring all companies to maintain confidentiality of data and adequate penalties for non-compliance.

Credit reporting is an important aspect of personal data protection. Credit reporting services supporting financial services providers are usually provided by credit registries, credit bureaus, or a combination of both.

Credit registries are generally administered by central banks and financial supervisory authorities. Banks and other financial institutions supply information to the credit registries about the financial obligations of their borrowers. The information is used for two main purposes: appraisal of the creditworthiness of prospective borrowers, and banking supervision activities.

When detailed information about individuals contained in credit registries is provided to regulated financial institutions, consumers have the right to access their personal information and to request corrections if the data is flawed or incomplete.

53 "...Shareholders, Chairman and members of the Board of Directors, the Executive Director and officers of a bank shall not release and disclose to others, or use any information which is considered by the bank, its customers, and/or third parties as confidential, except in the following cases: 7.2.1. the individual to whom confidential information relates agreed in writing to disclosure; 7.2.2. the Bank of Mongolia and its supervisors demanded in relation to performing their legitimate duties; 7.2.3. the court and prosecutor's office management lodged a request and/or the prosecutor's office accepted the request from management of the anti-corruption authority and police department due to their case registration and investigation work requirements; 7.2.4. if the violation of laws of Mongolia is proven, at the request of an international law enforcement institution or Government of a foreign country which has concluded with Mongolia an Agreement on Legal Assistance; 7.2.5. the FRC demanded for supervising licensed activities and/ or financial regulatory authority of a foreign country requested in line with the FRC's obligation under an international treaty. 7.3. Confidentially requirements described in provision 7.2 of this Law shall not apply to inter-bank data on bank lending, information to be furnished under the law and agreement on credit bureau, reports and data set forth in Articles 37 and 38 of this Law, and information exchanged between the bank and the issuer of asset-backed securities...". Banking Law, Articles 7.2 and 7.3.

54 However, BOM Governor's Decree A-18 of 08 Feb. 2012, General guidance for on-site inspection of banks by supervision department of $B O M$ deals partly with risk prevention related to information system infrastructures. 
Credit bureaus, on the other hand, are run by the financial industry or independent third parties. They are usually more complex organizations and tend to gather information from a greater variety of data sources, such as utility companies and non-financial companies providing trade credit, in addition to financial credit institutions. Credit bureaus are often utilized by financial services providers as well as other users. Credit bureaus generally allow consumers free access to reports that concern them at least once a year and the ability to request corrections.

Credit bureaus and credit registries include two main types of data: data allowing for the correct identification of the borrower, and data about the borrower's indebtedness.

For individual consumers, the data includes the name and address of the individual, loan information (type, maturity, guarantees, collateral value, etc.), and payment arrears and defaults. The quality and completeness of the information is an essential component of an effective credit reporting system. Inaccurate data may lead to unjustified loan denials or to higher borrowing costs. ${ }^{55}$

Credit reporting systems must be subject to adequate oversight, with sufficient enforcement power assigned to the supervisory authorities (data protection agencies and financial regulatory bodies). They must rely on accurate and up-to-date information. ${ }^{56}$

Different approaches have emerged with respect to protecting the privacy of sensitive and confidential consumer data. For example, a comparison can be made between the European Union and the United States.

The European Union has adopted a directive covering data subject protection rights with across the board application and specific regulations applicable to credit reporting systems (Box 5). Conversely, the United States has adopted a specific legal framework, the Fair Credit Reporting Act, which applies to consumer data used for the credit reporting system.

In Mongolia, credit reporting activities by state-owned credit registries and privately-owned credit bureaus are regulated by the Credit information Law. ${ }^{57}$ The law applies to banks, non-bank financial institutions, and savings and credit cooperatives. The law allows private entities to conduct credit information activities after obtaining a license from the BOM, which is also responsible for supervision. However, the law is not yet operational as it requires the adoption of two implementing regulations on the criteria for issuing licenses for credit bureaus and the principles and rules for information exchanges between the existing BOM-managed credit registry and the credit bureaus ${ }^{58}$.

55 The most important features for the definition of accurate data are:

- The data must be able to capture the relevant detailed information, including positive and negative data, on a given individual. Positive data includes account balances and on-time payments. Negative data includes late payments, defaults, bankruptcies and court judgements;

- The data must be based on information from as many data providers as possible, within the limits prescribed by law; and

- The information must cover a sufficient time span.

56 "Effective Approaches to Support the Implementation of the Remaining G20/OECD High Level Principles on Financial Consumer Protection" OECD, September 9, 2004, pp. 44-49.

57 Adopted by Parliament in October, 2010.

58 "...Regulations concerning on to grant special permission to conduct credit information operation, to build-up credit information database, to process/digest, retain, protect, transfer the credit information and pricing of the service shall be set by BOM...". Law on Credit Information, Article 23.4.). 


\section{Box 5: Protection of Personal Data in the European Union}

In 1995, the European Union member states adopted a common legal framework (Directive) for the protection of individuals' personal data which applies across-the-board to all markets and activities, including banking and financial services. Both data processed by automated means (e.g. a computer database of customers) and data contained in or intended to be part traditional paper files are covered. The directive aims to protect the rights and freedoms of persons in the processing of personal data. It provides guidance to determine when data processing is lawful and when it is not. The directive states that every person shall have the right to a judicial remedy for any breach of the rights guaranteed by the national law. In addition, any person who has suffered damage as a result of the unlawful processing of their personal data is entitled to receive compensation for the damage suffered. Each member state is required to establish one or more independent public authorities responsible for monitoring the application within its territory of the provisions adopted by the member states pursuant to the Directive.

The details can be found in Directive 95/46/EC of 24 October 1995 "on the Protection of Individuals with regard to the Processing of Personal Data and on the Free Movement of such Data".

Source: European Union. 1995. Directive 95/46/EC of the European Parliament and of the Council of 24 October 1995. https://eur-lex. europa.eu/legal-content/en/TXT/?uri=CELEX\%3A31995L0046.

The existing Credit Registry, managed by the $\mathrm{BOM}$, relies on a database of credit information covering 1 million individuals and 10,000 legal entities. The registry includes information about outstanding debt obligations, overdue payments and defaults, and rejected credit ${ }^{59}$ Borrowers' consent is not required. The credit registry is used for prudential supervision purposes and to provide support to regulated lending institutions to assess the credit risk of the prospective borrowers. Concerning confidentiality with respect to credit reporting activities, the Credit Information Law requires that credit reporting and information activities carried out by licensed private credit bureaus should receive "...permission from the borrowers..."..and should "...ensure confidentiality of the information...". ${ }^{60,61}$ The Law requires all lending institutions (banks, non-banks financial institutions, savings and credit cooperatives) to provide data to the BOM credit information database, regardless of whether the borrower - either individual or a legal entity - has or has not given permission. The Law also contains rules for the establishment and operation of private credit operated by the private sector. So far, no license has been issued for any private credit bureaus. Unlike the BOM credit information database, private credit bureaus must obtain borrower's permission in order to add data to their credit information database. According to the law, the consumer has the right to demand compensation for damages when they suffer harm derived from inaccurate information. ${ }^{62}$ The Credit Information Law appears to provide adequate rights to the borrowers. Consumers can make inquiries and examine their personal information and have access to their personal record once a year. If the credit information database is not accurate and complete, the consumer can request credit information suppliers and credit information services providers to revise the information. However, at present the BOM does not have any binding power to resolve disputes

${ }^{59}$ Credit Information Law of Mongolia. https://www.mongolbank.mn/documents/law/zeeliinmedeeleleng.pdf.

60 “...Following principle shall be adopted/adhered for providing credit information service:...it's mandatory to obtain permission from borrowers...". Credit Information Law, Article 5.1.2

61 “...Following principle shall be adopted/adhered for providing credit information service:...to provide confidentiality...”. Credit Information Law, Article 5.1.5.

62 “...User has following rights ...If any damage occurs because of providing wrong information intentionally, to require to compensate the damage...". Credit Information Law, Article 21.1.3. 
between banks and consumers. The BOM intends to ultimately delegate credit reporting activities to the private sector when they deem this will be suitable. ${ }^{63}$

\section{RECOMMENDATIONS FOR STRENGTHENING PRIVACY AND PERSONAL DATA PROTECTION IN BANKING AND FINANCIAL SERVICES}

\section{Adopt a comprehensive data protection law with adequate penalties for non-compliance.}

At present, Mongolia does not have a general and comprehensive law with detailed rules for enterprises, including banks, to protect personal data and safeguard individuals' privacy. The adoption of such law in the medium term would help strengthen financial consumer protection. Adequate penalties for non-compliance with the data protection rules should be included in the law to deter infringement of its provisions.

\section{Regulate banks' use of personal data collected as part of banking activities.}

The BOM should require banks to inform customers about any existing statutory requirement to release information to Government authorities about their individual accounts and what the data can be used for. The BOM should also require banks to inform customers in writing about any legal requirement they have with respect to sharing customer account information with third parties, such as credit bureaus or credit registries. Banks should be prohibited from sharing or selling customer information for telemarketing or similar purposes without the customer's explicit consent.

\section{ALTERNATIVE DISPUTE RESOLUTION}

While all banks in Mongolia appear to have set up some form of internal mechanisms and procedures to handle customer complaints, they do not share the details of the procedures with their actual or potential customers. Consequently, consumers may not know how to resolve a dispute with their bank.

When customers enter into a contractual relationship with a bank, they are not provided with information on how to file a complaint. Banks' terms and conditions (contractual arrangements) do not refer to their complaint-handling procedures, nor do they indicate the contact person or internal unit in charge of complaints. Customers also are not told how to find the full text of the complaint procedures. The BOM has not issued compulsory standardized internal complaint-handling procedures, to be complied with by all banks, nor any guidance on:

- Setting up complaint-handling services;

- Designating a contact person or unit to deal with complaints, and communicating with the public about the same;

- Requiring strict compliance with the written procedures when dealing with complaints;

- Making written procedures readily available to those that request them;

- Including a summary of the complaint procedures in the terms and conditions;

- Maintaining an up-to-date record of complaints (including complainant's details, nature of complaint, banks' replies) and how they were resolved; or

- Sharing the complaints record with the BOM, upon request, for review.

${ }^{63}$ Central Bank of Mongolia. https://www.mongolbank.mn/news.aspx?id=1187. 
There is no requirement for banks to provide aggregate data and statistics to BOM with respect to the consumer complaints submitted to them, nor with respect to how the complaints were dealt with.

For consumer complaints that cannot be resolved directly with the bank, the Consumer Protection Law includes, among the listed consumer rights, the right to obtain redress for any harm suffered by the consumer. ${ }^{64}$ However, the AFCCR, Mongolia's consumer protection enforcement agency, has not been assigned any binding power to settle disputes between enterprises (including banks) and consumers or to compensate consumers for harm due to unfair behavior. Similarly, the DPSLA Law states that depositors can file a claim with the relevant regulatory authorities (i.e. the BOM) or with the courts in order to obtain some form of reimbursement in case of harm. ${ }^{65}$ However, the BOM also has no clear binding alternative dispute-resolution power. All the BOM (and the AFCCR for the financial markets under its supervision) can do at present is hear the case and informally propose a solution to the two disputing parties. However, banks are not required to comply with the BOM's proposal.

Consumers can ultimately bring disputes to Mongolia's District Courts which have first instance jurisdiction over cases related to consumer harm. However, in view of the requirement for the concerned consumer to make use of professional legal assistance, and considering the District Courts' lack of expertise with respect to consumer protection, recourse to the District Courts does not seem practical for consumers in relatively small disputes with banks.

\section{RECOMMENDATIONS CONCERNING THE RESOLUTION OF DISPUTES AND THE ESTABLISHMENT OF A FINANCIAL OMBUDSMAN}

\section{Adopt required minimum standards for handling disputes.}

The BOM should require all banks to have in place a standardized scheme to deal fairly, effectively, and rapidly with customers' complaints. The BOM should consult with the MBA and consumer organizations before establishing binding procedures.

Each bank should include a summary of its internal procedures for consumer complaints in its general terms and conditions and in the key facts statements. The complete version of the complaint-handling procedure should made available to consumers online and on paper in the bank's "brick and mortar" branches. The BOM should require banks to acknowledge the receipt of a consumer's complaint in writing, with reference to the bank officer or internal unit responsible for handling the complaint. Banks should also be required to resolve the complaint within a reasonable time-frame and, in cases that require longer time, to provide periodic updates to the complainant.

After closing the investigation of a complaint, banks should, in a timely manner, inform the consumer of the outcome and of any settlement offered. At the same time, the consumer should be informed of any recourse he or she has through the $\mathrm{BOM}$ or the dispute-settlement body if he or she is not satisfied with the handling of the case. Banks should be required to maintain a record of complaints, including their

\footnotetext{
64 "...The following principles shall be adhered to in consumer protection:.. "...Any harm caused to the consumer's health, life, property, non-property interests and environment shall be redressed, the violated rights restored, and losses compensated for." Consumer Protection Law, Article 4.

65 "...Depositor and depository shall have the following rights and duties as provided in the deposit agreement in accordance with the requirements of article 367 of the Civil Law of Mongolia and article 8 of the Banking Law of Mongolia:.. A depositor... may bring a claim for compensation for loss suffered as a result of the failure of a bank to fulfill its duties properly to concerning authorities or to the court." DSPLA Law, Article 7.
} 
content and resolution, to allow the BOM (and alternative dispute resolution body when established) for monitoring purposes. They should also provide aggregate statistics of the complaints to the BOM.

\section{Adopt a binding alternative dispute resolution mechanism.}

In all jurisdictions, including Mongolia, many disputes between banks and financial service providers (FSP) and consumers involve relatively minor pecuniary damage and have a relatively minor impact on the individual consumer. ${ }^{66}$ It would not be feasible for Mongolia consumers to take legal action for such disputes, in view of the cost and inconvenience related to judicial proceedings and the relatively minor benefits.

Further, a revised legal and regulatory framework for financial consumer protection should provide a stronger legal mandate to the BOM; it would not be practical for the BOM (and the FRC) to deal with complaints involving the violation of consumer rights. Such a role is more appropriately assigned to a separate alternative dispute resolution (ADR) body, preferably with binding adjudicatory powers covering all financial disputes (banking, insurance, investment, etc.). ${ }^{67}$ The ADR would provide an alternative to courts for consumers having an unresolved dispute with an FSP with The BOM and FRC acting as supporting Secretariat. This would also reduce the burden on the judiciary.

To ensure full effectiveness and a positive contribution to sound financial consumer protection, it is important for the ADR to be viewed as independent and respected as a judge by both the consumers and the FSPs involved in a dispute. ${ }^{68}$ The ADR should therefore be staffed by persons with the necessary legal and technical expertise to effectively solve disputes. ${ }^{69}$

\section{Ensure a high degree of independence for the ADR.}

The ADR body may consist of one individual, or a collegiate body. An individual appointed as ADR may be drawn from an existing public institution but should nevertheless carry out dispute resolution interventions in an independent manner, including vis-a-vis the appointing institutions.

When the ADR is established as a collegiate body, it may include representation by a number of different stakeholders. However, it is essential that the composition of the ADR is not determined or proposed in

${ }^{66}$ An example could be an automatic ATM not dispensing the cash charged but still recording the provision of cash.

67 The fundamental contribution of ADR mechanisms to a sound financial consumer protection legal framework was explicitly stated in Section 9 of the High-Level Principles on Financial Consumer Protection endorsed by the G-20 Finance Ministers and Central Bank Governors at their meeting on 14-15 October, 2011. This section states: "...Jurisdictions should ensure that consumers have access to adequate complaints handling and redress mechanisms that are accessible, affordable, independent, fair, accountable, timely and efficient. Such mechanisms should not impose unreasonable cost, delays or burdens on consumers. In accordance with the above, financial services providers and authorized agents should have in place mechanisms for complaint handling and redress. Recourse to an independent redress process should be available to address complaints that are not efficiently resolved via the financial services providers and authorized agents internal dispute resolution mechanisms. At a minimum, aggregate information with respect to complaints and their resolutions should be made public...".

68 The statutes of the financial ADR in several jurisdictions explicitly require that the person(s) appointed as financial ADR must not have worked for a FSP or an industry association for at least 3-4 years preceding the appointment, in order to avoid conflicts of interest which may undermine the financial ADR's credibility. This clearly would not apply in case of ADRs which explicitly foresee a representation of the financial industry.

${ }^{69}$ In several jurisdictions, the ADR is not an individual decision-maker: rather, it encompasses a plurality of persons, each of them being assigned ADR powers. In the UK, for example, no single ADR exists, but rather a pool of them. The panel is led by a "Chief Financial ADR" who does not have power to influence the decisions taken by the individual ombudsman. Along with the Chief Financial ADR, a senior ombudsman and about 200 other ombudsmen form the FSO. 
any way by just one of the involved stakeholders, such as FSPs or the industry associations representing their interests. It is also important that the financial industry not be allowed to influence the financial ADR's remuneration. Preferably, the ADR' salary is linked to that of a high-ranking judge or public official.

The person or persons appointed as ADR should be given a term of adequate length, allowing sufficient time to carry out the work with effectiveness and independence. ${ }^{70}$

\section{Consider alternative sources for funding the financial ADR.}

The ADR's activity could be financed in Mongolia directly through a designated share of the State. Alternatively, and probably preferably, the funds to cover the expenditures of the ADR could be raised through a levy on all banks and financial services providers, according to their size. Funding is derived from industry participants in a significant number of countries. ${ }^{71}$

If funding is to be sourced from the banking and financial services industry, two options for allocating the ADR's costs among industry players can be considered. The most frequent method of allocating these costs is to request all financial to contribute based on their relative market share or turnover. A second alternative would be to set the individual contribution according to the number of cases which were brought to the ADR involving the particular firm.

Jurisdictions which require contributions proportional to the number of cases dealt with often set a minimum number of cases below which FSPs are not charged. For example, in the United Kingdom, the financial ADR only charges companies beginning with company's the $26^{\text {th }}$ case; the first 25 are free of charge. This approach minimizes the risk of small FSPs being blackmailed by dishonest individuals presenting fake complaints to force the company to pay ADR charges.

There is a general understanding that imposing even a small levy on consumers for taking advantage of ADR services would represent a barrier, particularly for those more vulnerable. Such a practice is therefore not advised for Mongolia.

\section{Assign appropriate powers to the ADR.}

An essential question to be decided by the Mongolian authorities is whether to make the decisions by the financial ADR legally binding on the involved parties, i.e. the bank/financial services provider and the consumer. ${ }^{72}$ In several countries which have established financial ADRs, the decisions are not binding on the involved parties. Nevertheless, since ADR decisions in most of those countries is made public, the publicity itself puts sufficient pressure on financial services operators to comply. It might be a valid option in the short-term to establish an ADR without binding decision-making power, as long as its decisions/ opinions are made public. After the initial phase, a binding mechanism can be introduced.

70 The discharge of an ADR should be foreseen only in clearly defined and serious circumstances, such as in case of severe misconduct or evident incapacity. The grounds for release should be explicitly defined in the relevant statute.

${ }^{71}$ Constraints on public expenditures in many countries is certainly a cause for drawing on alternative sources. Another reason that the financial industry is being increasingly called on to cover the financial ADR' expenses is the belief that greater confidence in the financial markets originating from the financial ADR's work also leads to a significant benefit for all industry participants.

72 In the United Kingdom, when the consumer accepts an ADR's final decision, that decision is binding in law on both the consumer and the business. 


\section{Box 6: The Role of the Financial System Mediator (Financial Ombudsman) in Armenia}

Armenia's Office of Financial System Mediator is called to resolve disputes between the individuals and financial institutions. Dispute resolution is free of charge and rapid. Established by the Central Bank of Armenia pursuant to the Republic of Armenia Law on Financial System Mediator, the Office has been operational since January 24, 2009.

The Office is a body with an independent management system. The Board of Trustees of the Office appoints the Mediator. The members of the Board of Trustees are appointed by the Government of the Republic of Armenia ( 1 member); the Board of the Central Bank of Armenia (1 member), industry associations (4 members), and organizations that advocate protection of consumer rights (1 member). The Office is funded through regular mandatory fees levied on licensed financial institutions (banks, credit organizations, insurance companies, pawnshops, etc.) as prescribed by law. The Office pursues the following objectives: protection of consumer rights and interests in the financial markets; fast, effective and free review and handling of client claims; and enhancement of public confidence in the financial sector. Within thirty days after the Financial System Mediator's decision is made public, and the customer consents in writing, the resolution is deemed mandatory for all parties. Parties may appeal the decision by addressing a competent court.

Source: Adapted from the submission by the representative of the Central Bank of Armenia at the ADB International Conference on Financial Consumer Protection, Ulaanbaatar, Mongolia, 12 October 2017.

An equally important subject is whether all FSPs would be statutorily required to be covered by a financial ADR with regard to unresolved disputes. To ensure greater protection for consumers, all banks and FSPs should be covered.

\section{Assign appropriate scope of coverage to the financial ADR.}

A trend emerging in several jurisdictions is to establish a single financial ADR, responsible for disputes concerning all categories of financial products and services: banking, investment, insurance, etc. This trend clearly goes in parallel with the tendency to establish a single regulatory body charged with regulating financial market conduct and consumer protection. Several reasons explain this orientation. ${ }^{73}$

First, the boundaries between the different types of financial services have become increasingly blurred. For example, banking institutions are increasingly active in the design and distribution of insurance and investment services. Second, an all-encompassing financial ADR provides the flexibility to move human and other resources around to adjust to changing needs in specific areas. Third, it is generally simpler for consumers to deal with a single ADR rather than several responsible for different industries.

Nevertheless, several jurisdictions do find it preferable to have separate ombudsmen for banking, investment, and insurance services, particularly those with separate supervisory agencies for specific financial services, as is currently the case in Mongolia. However, given that the overall financial services market is small and the Mongolian state and financial industry have limited resources, it is preferable to establish a single, industry-wide financial ADR.

Financial ADRs commonly cover all market players providing financial products and services. An ADR covering only the members of a specific industry association or only national financial services providers

\footnotetext{
73 For a more detailed analysis of the causes behind the establishment of a general Financial ADR please see: Resolving disputes between consumers and financial businesses: Fundamentals for a financial ADR. A practical guide based on experience in western Europe" by David Thomas and Francis Frizon, January 2012, The World Bank Global Program on Consumer Protection, pp. 38-40.
} 
would be less effective. Credit bureaus are also generally placed under the financial ADR, given their impact on financial consumers. It will be useful for Mongolia to follow the same path.

Most established financial ADRs appears address only disputes involving consumers. However, some jurisdictions, such as the Republic of Ireland, extend the financial ADR coverage to small or micro enterprises. Those jurisdictions usually set a threshold above which firms would not be considered small, and therefore not allowed to present disputes to the ADR. The threshold usually reflects the company's turnover or number of employees.

ADR coverage of small enterprises is often justified on the grounds that such enterprises have limited technical and financial capabilities. In this way they are more similar to individual consumers than to enterprises and require a degree of protection similar to that assigned to consumers. In any case, it is not advisable for ADRs to handle disputes between two or more financial services providers. ${ }^{74}$

Mongolia may introduce the financial ADR in increments, extending the service only to existing individual customers in the short-term. ${ }^{75}$ In most jurisdictions, statutory rules specify whether the financial ADR can deal only with disputes which have arisen after the ADR's establishment or whether they can also deal with pre-existing disputes. In general, only the ADR has the responsibility to decide whether a given complaint falls within its jurisdiction. Time limits are usually set for the interval between the event that caused the dispute and the complaint to the Financial ADR, and the interval between a final rejection by the financial institution of the consumer's complaint and the complaint to the financial ADR. ${ }^{76}$

\section{Establish effective and efficient procedures.}

In most jurisdictions, consumers are required to attempt to resolve a dispute directly with the institution involved before being allowed to appeal to the $\mathrm{ADR}^{77}$. This requirement should apply to a revised Mongolian financial consumer protection framework establishing a financial ADR for all financial services.

In many jurisdictions, financial institutions are required by statute to have in place a fair, effective and timely internal dispute resolution system which is well publicized among consumers. ${ }^{78} \mathrm{~A}$ similar practice, albeit in a non-standardized form, appears to be already in place in Mongolia. However, it would be useful to strengthen this requirement.

Financial ADRs usually have facilities in place to deal with phone, email and written consumer enquiries. These facilities complement written or online guidance aimed at providing information about dispute the

74 "Resolving disputes between consumers and financial businesses: Fundamentals for a financial Ombudsman. A practical guide based on experience in western Europe" by David Thomas and Francis Frizon, January 2012, The World Bank Global Program on Consumer Protection, pp. 41-42.

75 Complaints to the financial ADR generally can be presented by potential customers of financial institutions, in addition to the existing clientele. For example, would-be customers can present a complaint against an FSP which refuses to provide products or services (discrimination cases).

76 Resolving disputes between consumers and financial businesses: Fundamentals for a financial Ombudsman. A practical guide based on experience in western Europe" by David Thomas and Francis Frizon, January 2012, The World Bank Global Program on Consumer Protection, pp. 33-35.

77 In the United Kingdom, the Financial ADR Service can deal with cases only if the consumer remains dissatisfied with the financial institution's final response, or if the institution has not presented a final response within eight weeks of the complaint.

${ }^{78}$ In Ireland, consumers are required by the Financial ADR to fill in a complaint form when they wish to present a dispute. The form is first submitted to the financial institution, which is given some time to reply, before any formal investigation is launched by the Financial ADR. 
resolution process and the role of the ADR. Handling enquiries appropriately helps reduce the number of formal complaint investigations. In most jurisdictions, only a small sub-set of complaints become full-blown cases. ${ }^{79}$ In cases where an investigation is launched, the ADR usually takes an active role in identifying what information is needed. In many jurisdictions, ADRs are assigned adequate statutory powers to access the relevant information for dealing with a dispute. ${ }^{80}$

It is customary to set a ceiling on the amount of financial compensation that can be awarded by the financial ADR in each individual case. The ceiling is also due to the fact that an ADR operates in more informal way than a tribunal. ${ }^{81}$ For larger sums, it is considered necessary to resort to the court system. ${ }^{82}$

\section{Ensure the ADR is accessible, transparent, and accountable.}

All financial ADRs have a website providing information to consumers on their role and activities. The sites also contain details on how consumers can present complaints and on how financial institutions should handle complaints. This would be useful for the financial ADR in Mongolia.

At the same time, it is important to make information available to consumers who do not use the Internet; this can be provided in public spaces, such as libraries or consumer advice centers. Many ADRs make a public commitment to ensure that all of their communication, including decisions, are written in a plain language to be easily understood by all consumers.

One of the aims of sound dispute resolution is to ensure that the ADR is held accountable for impartiality and quality of work. Accountability should not in any way constrain the independence of the ADR. On the contrary, it should ensure a transparent and independent dispute resolution process.

Most ADRs publish an annual report of their activities. These typically contain statistics about the types of complaints received and information on how cases were resolved. ${ }^{83}$ This procedure seems appropriate in the Mongolian context.

It is important for financial ADRs to provide relevant feedback to the legislative and regulatory authorities about systemic issues affecting consumers so that appropriate measures can be taken to correct them. Some financial ADRs conduct advance consultations with the public concerning their procedures, priorities, and activities. The resulting feedback is considered an important part of the planning process and makes the ADR more effective and consumer-friendly.

${ }^{79}$ In the United Kingdom, for example, the Financial ADR Service always attempts first to settle cases through mediation and conciliation between the parties in dispute. The ADR adjudicators, who deal with cases before they are submitted to the ombudsman, present their views to the parties, which in most cases agree with the recommendations for settling the dispute. Only one case out of ten requires a final formal decision by an ADR.

80 The involved parties are often allowed to present their views, be informed about each other's position, and have access to the record, including any report presented by experts. However, no access to confidential information is granted. The decision by the financial ADR is most often delivered in writing and provides the reasoning on which it is based. Usually, consumers are not required to engage a lawyer for dispute resolution with the financial ADR. However, neither are they prevented from doing so.

81 The UK Financial ADR Service can instruct a financial institution to pay up to $£ 150.000$ for "...financial loss - and/or pain and suffering, damage to reputation, distress and inconvenience...". See "A Quick Guide to how we handle disputes between businesses and consumers" produced by the FSO.

82 In Europe, if the ADR decision is binding on the parties, some form of oversight by the courts is viewed necessary to ensure compliance with the European Convention on Human Rights.

83 In the UK, the Financial Ombudsman Service publishes a regular newsletter, financial ADR news, with articles on the approach taken to different types of complaints. The search facility on the ADR website helps consumers and financial institutions to track down how similar cases have been handled in the past. 


\section{THE INTERFACE BETWEEN COMPETITION AND FINANCIAL CONSUMER PROTECTION}

Mongolia's competition law enforcement agency, the AFCCR, has not actively enforced consumer protection and the promotion of competition in the banking industry, due to scarce resources and other pressing priorities. Also, no studies have been undertaken to assess the degree of competition in the industry or to identify initiatives which could strengthen competition to the benefit of consumers. No formal cooperation or consultation mechanisms exist between the AFCCR, the BOM, and the banking regulator.

\section{RECOMMENDATIONS ON THE RELATIONSHIP BETWEEN COMPETITION POLICY AND FINANCIAL CONSUMER PROTECTION}

\section{Strengthen competition law and policy enforcement in the banking industry.}

Financial regulators recognize that strong competition among financial service providers constitutes an incentive to firms to ensure that consumers are supplied with high-quality financial products and services and that the financial markets operate efficiently. Mongolia has increasingly relied on market forces to determine the price, quality and range of products and services, including banking and financial services. In this regard, the promotion of competition in the financial markets should be an integral component of a revised financial consumer protection framework and a policy priority for both the financial regulatory agencies and the competition enforcement agency. ${ }^{84}$

\section{Establish formal consultation mechanisms between the BOM and the competition enforcement agency.}

In a revised financial consumer protection framework, the competition enforcement agency should be required by statute to consult the banking supervisory authority (BOM) when taking competition legislation enforcement actions in banking markets.

\section{CONCLUSIONS}

As the current regulatory regime does not afford adequate protection and disclosure for consumers, Mongolian citizens are unable to enjoy transparent, fair and efficient banking and financial services.

The implementation of a strong legislative and regulatory framework for the protection of financial consumers will enhance the welfare of Mongolian citizens and strengthen their overall confidence in the financial industry. This will ultimately benefit market operators and produce a significant spillover to the whole Mongolian economy.

Clearly, the adoption of the new legislative and regulatory framework must be matched by a strong supervisory role for the BOM to ensure financial services providers comply with the new obligations. Coupling the adoption of new rules with sound supervision of their implementation is equally important. In view of the current human and financial resource constraints, advances in financial consumer protection in Mongolia will be difficult to achieve. However, the potential benefits of doing so will be significant.

${ }^{84}$ In the United Kingdom, one of the three statutory objectives that the Financial Conduct Authority must pursue is the promotion of effective competition in the interests of consumers in the markets it regulates. 


\section{REFERENCES}

Alliance for Financial Inclusion. 2016. Market Conduct Supervision of Financial Services ProvidersA Risk-Based Supervision Framework. Kuala Lumpur. https://www.afi-global.org/sites/default/files/ publications/2016-08/Guideline\%20Note-21\%20CEMC-RiskBased.pdf.

Australian Bankers' Association, Inc. 2013. Code of Banking Practice. Sydney. https://www.ausbanking. org.au/wp-content/uploads/2019/04/2013_ABA_CODE.pdf.

Authority for Financial Markets. 2013. Product Oversight for Financial Institutions-Balanced Consideration of Customer Interests in Product Development. The Netherlands.

Bank of Italy. 2009. Transparency of Banking and Financial Operations and Services and Financial Institutions' Fair Dealing with Customers.

S. di Castri. 2011. Empowering and Protecting Financial Consumers-Bank Negara Malaysia's Consumer and Market Conduct Framework. Alliance for Financial Inclusion. https://ssrn.com/abstract=1843281.

Consumer Protection Code 2012. Republic of Ireland. https://www.centralbank.ie/docs/default-source/ regulation/consumer-protection/other-codes-of-conduct/4-gns-4-2-7-cp-code-2012. pdf?sfvrsn=4.

D. Dias. 2013. Implementing Consumer Protection in Emerging Markets and Developing Economies: A Technical Guide for Bank Supervisors. Washington, DC: World Bank Group. http://documents. worldbank.org/curated/en/802151468328788275/Implementing-consumer-protection-inemerging-markets-and-developing-economies-a-technical-guide-for-bank-supervisors.

Directive 2014/17/EU of the European Parliament and of The Council of 4 February 2014 on credit agreements for consumers relating to residential immovable property and amending Directives 2008/48/EC and 2013/36/EU and Regulation (EU) No 1093/2010 (Directive on Mortgage loans).

European Commission. 2005. Sectorial Inquiry on the Retail Financial Services Sector.

- Mortgage Credit-Directive 2014/17/EU. https://ec.europa.eu/info/law/mortgage-creditdirective-2014-17-eu_en (accessed 16 December 2019).

European Union. 1995. Directive 95/46/EC of the European Parliament and of the Council of 24 October 1995. https://eur-lex.europa.eu/legal-content/en/TXT/?uri=CELEX\%3A31995L0046.

Financial Stability Board. 2011. Consumer Finance Protection with Particular Focus on Credit. https://www. fsb.org/wp-content/uploads/r_111026a.pdf.

Government of the United States of America. 2010. Public Law 111-203 Dodd-Frank Wall Street Reform and Consumer Protection Act. Washington, DC. https://www.congress.gov/bill/111th-congress/ house-bill/4173/text?overview=closed $\& r=1$.

Microfinance CEO Working Group. 2015. Client Protection Principles: Model Law and Commentary for Financial Consumer Protection. DLA Piper. USA.

Organisation for Economic Co-operation and Development. 2011. G20 High Level Principles of Financial Consumer Protection. Paris. https://www.oecd.org/daf/fin/financial-markets/48892010.pdf.

2004. Effective Approaches to Support the Implementation of the Remaining G20/OECD High Level Principles on Financial Consumer Protection. Paris.

D. Thomas and F. Frizon. 2012. Resolving Disputes between Consumers and Financial Businesses: Fundamentals for a Financial Ombudsman-A Practical Guide Based on Experience in Western Europe. World Bank Global Program on Consumer Protection. Washington, DC: World Bank. 
http://documents.worldbank.org/curated/en/169791468233091885/a-practical-guide-basedon-experience-in-western-Europe.

World Bank. 2014a. Establishing a Financial Consumer Protection Supervision Department: Key Observations and Lessons Learned in Five Case Study Countries. Washington, DC. https://openknowledge. worldbank.org/handle/10986/25894.

2014b. Global Survey on Consumer Protection and Financial Literacy: Oversight Frameworks and Practices in 114 Economies. Washington, DC. https://openknowledge.worldbank.org/ handle/10986/18978.

. 2012. Good Practices for Financial Consumer Protection. Washington, DC. https://siteresources. worldbank.org/EXTFINANCIALSECTOR/Resources/Good_Practices_for_Financial_CP.pdf. 


\section{Strengthening the Protection of Financial Consumers in Mongolia's Banking Sector}

This working paper discusses the results of a critical review of the existing financial consumer protection framework in Mongolia. The assessment includes recommendations for Mongolian policy makers on ways to improve the regulatory framework and the supervisory oversight of financial consumer protection and the role that the Bank of Mongolia could play. The analysis focuses on the banking industry in Mongolia, which currently accounts for over $90 \%$ of the entire financial services industry. However, a significant number of the proposed recommendations may be equally applicable to other financial markets, such as insurance and investment and securities services, and several unregulated services.

\section{About the Asian Development Bank}

ADB is committed to achieving a prosperous, inclusive, resilient, and sustainable Asia and the Pacific, while sustaining its efforts to eradicate extreme poverty. Established in 1966, it is owned by 68 members -49 from the region. Its main instruments for helping its developing member countries are policy dialogue, loans, equity investments, guarantees, grants, and technical assistance. 